\title{
The Epidemiology and Geographic Distribution of Relapsing Fever Borreliosis in West and North Africa, with a Review of the Ornithodoros erraticus Complex (Acari: Ixodida)
}

\author{
Jean-François Trape ${ }^{1 *}$, Georges Diatta ${ }^{1}$, Céline Arnathau ${ }^{2}$, Idir Bitam ${ }^{3}$, M'hammed Sarih ${ }^{4}$, Driss Belghyti ${ }^{5}$, \\ Ali Bouattour ${ }^{6}$, Eric Elguero ${ }^{2}$, Laurence Vial ${ }^{1,2}$, Youssouph Mané ${ }^{1}$, Cellou Baldé ${ }^{7}$, Franck Pugnolle ${ }^{2}$, Gilles \\ Chauvancy $^{1}$, Gil Mahé ${ }^{8}$, Laurent Granjon ${ }^{9}$, Jean-Marc Duplantier ${ }^{9}$, Patrick Durand ${ }^{2 \odot}$, François Renaud ${ }^{2 \odot}$ \\ 1 Institut de recherche pour le développement, Laboratoire de Paludologie Et Zoologie Médicale, Dakar, Senegal, 2 Institut de Recherche pour le \\ Développement, UMR (CNRS IRD) MIVEGEC, Montpellier, France, 3 Institut Pasteur d'Algérie, Laboratoire d'Écologie des Systèmes Vectoriels, Algiers, \\ Algeria, 4 Institut Pasteur du Maroc, Laboratoire des Maladies Vectorielles, Casablanca, Morocco, 5 Université lbn Tofail, Département de Biologie, Faculté des \\ Sciences, Kénitra, Morocco, 6 Institut Pasteur de Tunis, Service d'Entomologie Médicale, Tunis, Tunisia, 7 Institut Pasteur de Guinée, Laboratoire \\ d'Entomologie Médicale et de Vénimologie, Kindia, Guinea, 8 Institut de Recherche pour le Développement, UMR Hydrosciences, Montpellier, France, 9 Institut \\ de Recherche pour le Développement, Centre de Biologie et de Gestion des Populations, Dakar, Senegal
}

\begin{abstract}
Background: Relapsing fever is the most frequent bacterial disease in Africa. Four main vector / pathogen complexes are classically recognized, with the louse Pediculus humanus acting as vector for $B$. recurrentis and the soft ticks Ornithodoros sonrai, O. erraticus and O. moubata acting as vectors for Borrelia crocidurae, B. hispanica and $B$. duttonii, respectively. Our aim was to investigate the epidemiology of the disease in West, North and Central Africa.

Methods And Findings: From 2002 to 2012, we conducted field surveys in 17 African countries and in Spain. We investigated the occurrence of Ornithodoros ticks in rodent burrows in 282 study sites. We collected 1,629 small mammals that may act as reservoir for Borrelia infections. Using molecular methods we studied genetic diversity among Ornithodoros ticks and Borrelia infections in ticks and small mammals. Of 9,870 burrows investigated, 1,196 $(12.1 \%)$ were inhabited by Ornithodoros ticks. In West Africa, the southern and eastern limits of the vectors and Borrelia infections in ticks and small mammals were $13^{\circ} \mathrm{N}$ and $01^{\circ} \mathrm{E}$, respectively. Molecular studies revealed the occurrence of nine different Ornithodoros species, including five species new for science, with six of them harboring Borrelia infections. Only B. crocidurae was found in West Africa and three Borrelia species were identified in North Africa: B. crocidurae, B. hispanica, and B. merionesi.

Conclusions: Borrelia Spirochetes responsible for relapsing fever in humans are highly prevalent both in Ornithodoros ticks and small mammals in North and West Africa but Ornithodoros ticks seem absent south of $13^{\circ} \mathrm{N}$ and small mammals are not infected in these regions. The number of Ornithodoros species acting as vector of relapsing fever is much higher than previously known.
\end{abstract}

Citation: Trape J-F, Diatta G, Arnathau C, Bitam I, Sarih M, et al. (2013) The Epidemiology and Geographic Distribution of Relapsing Fever Borreliosis in West and North Africa, with a Review of the Ornithodoros erraticus Complex (Acari: Ixodida). PLoS ONE 8(11): e78473. doi:10.1371/journal.pone.0078473

Editor: Sven Bergström, Umeå University, Sweden

Received March 29, 2013; Accepted September 6, 2013; Published November 4, 2013

Copyright: $\odot 2013$ Trape et al. This is an open-access article distributed under the terms of the Creative Commons Attribution License, which permits unrestricted use, distribution, and reproduction in any medium, provided the original author and source are credited.

Funding: The study received grants from the GICC programme of the French Ministry of Ecology (ref: CV02000201), the programmes "Santé-

Environnement" and "Santé-Travail" of the Agence Nationale de la Recherche (ref: 3215AO-3R077-STEV), and the IRD special programme "Evolution Climatique et Santé" (ref: IRD-ATI-ECS). The funders had no role in study design, data collection and analysis, decision to publish, or preparation of the manuscript.

Competing interests: The authors have declared that no competing interest exist.

*E-mail: jean-francois.trape@ird.fr

• These authors contributed equally to this work. 


\section{Introduction}

Relapsing fever has long been recognized as major cause of disease and death in several regions of Africa [1-5]. Initially discovered in India in 1907 [6], the responsibility of Pediculus humanus in the transmission of Borrelia recurrentis, the Obermeier's spirochete, was confirmed the following year in Algeria [7]. Dramatic epidemics of louse-borne relapsing fever (LBRF) responsible for several millions of cases and a high fatality rate occurred throughout Africa after World Wars I and II when French and British colonial soldiers infected in Europe or North Africa returned to their countries [8-12]. More recently, several epidemics occurred in Sudan and LBRF still persists in the mountains of Ethiopia where it is endemic and can account for up to $27 \%$ of hospital admissions [5,13-16]. Tick-borne relapsing fever (TBRF) was first recognized in East Africa in 1904 [17,18], in North Africa in 1928 [19], and in West Africa in 1932 [20]. Studies conducted between 1905 and 1960 progressively established the classical picture of TBRF in Africa, with three different vector/pathogen complexes involving soft ticks (Argasidae) of the genus Ornithodoros. In the savanna areas of eastern and southern Africa, from $16^{\circ} \mathrm{N}$ (Erythrea) to $34^{\circ} \mathrm{S}$ (Cape province, South Africa), TBRF is caused by Borrelia duttonii with O. moubata s.I. as vector [21]. In the wild, the two vector species of the $O$. moubata complex (O. moubata s.s. and O. porcinus) lives in large animal burrows of antbears, warthogs and porcupines [22]. They have adapted secondarily to human dwellings and domestic animal shelters, where they live in the cracks of walls and floors. There is no known mammal reservoir of the disease and O. moubata s.I. act both as the vector and the only reservoir of $B$. duttonii [23]. The annual incidence of the disease may reach up to 384 per thousand among children <1 year of age and 163 per thousand in children $<5$ years of age in Tanzania [24], and a lethality rate of $16 \%$ among pregnant women suffering from the disease has been reported from Rwanda [25]. In North Africa, from Morocco to Algeria and Tunisia, TBRF is classically caused by Borrelia hispanica with $O$. erraticus as vector and small mammals as reservoir host [2,26-31]. $O$. erraticus is found both in large and small burrows, under stones, and has adapted to domestic animal shelters. Most human infections occur during summer among people sleeping in the fields or in farm buildings [32]. In West Africa, TBRF is caused by Borrelia crocidurae, with $O$. sonrai as vector and rodents and insectivores as reservoir host [33-37]. Most reports of the disease are from Senegal, but the few available data on the occurrence of the vector also include Mali, Mauritania, southern Morocco, Niger, Chad, Egypt and Kenya [23]. O. sonrai inhabits rodent burrows and like the other Ornithodoros species, it is a rapid feeder, blood meals lasting only a few minutes. People are generally infected during their sleep, when burrows open into their bedrooms [36].

The high incidence of TBRF in places where it was specifically investigated contrasts with the rarity of reports from other areas, suggesting than most cases remain undiagnosed because usually confused with malaria whose diagnosis is usually based only on clinical symptoms [38]. In Senegal, as a result of the ongoing drought since the 1970s, the tick has colonized the Sudan savanna, with the $750 \mathrm{~mm}$ isohyet as southern limit [36]. Rodent burrows colonized by $O$. sonrai occur in $87 \%$ of villages north of $13^{\circ} 30^{\prime} \mathrm{N}$. In these areas, we have shown that the average incidence of TBRF at the community level is the highest described for any bacterial disease, reaching 11 per 100 person-years [39]. In out-patients clinics, TBRF is the second most common cause of fever after malaria [38]. These observations in Senegal have prompted us to investigate the distribution and epidemiology of TBRF in West, North, and Central Africa. Here we present the result of studies conducted between 2002 and 2012 in 17 African countries.

\section{Methods}

\section{Ticks sampling}

To investigate the geographic distribution of Ornithodoros ticks, we conducted four series of studies

i) One transect study along the 14th parallel in Senegal, Mali, Burkina Faso, Niger and Chad, from $16^{\circ} \mathrm{W}$ (near the Atlantic coast of Senegal) to $22^{\circ} \mathrm{E}$ (near the border of Sudan in Chad). Sampling was conducted at each two degrees of longitude (i.e. at $16^{\circ} \mathrm{W} / 14^{\circ} \mathrm{N}, 14^{\circ} \mathrm{W} / 14^{\circ} \mathrm{N}, 12^{\circ} \mathrm{W} / 14^{\circ} \mathrm{N}$, and up to $22^{\circ} \mathrm{E} / 14^{\circ} \mathrm{N}$ ), either at the exact meridian/parallel junction point as determined with a Global Positioning System (GPS) receiver, or depending on the accessibility of this point and local environment, within a 10' radius around it (i.e. maximum distance: $20 \mathrm{~km}$ ). The 14th parallel was selected since it was entirely located within the limits of the supposed range of $O$. sonrai (presumed southern limit: $750 \mathrm{~mm}$ isohyet, period 1970-2002) [36].

ii) Three North/South transect studies along three meridians: $12^{\circ} \mathrm{W}$ (in Morocco, Mauritania, Senegal, and Guinea), $2^{\circ} \mathrm{E}$ (in Mali, Niger, Burkina Faso and Benin), and $14^{\circ} \mathrm{E}$ (in Chad and Cameroon). Sampling was undertaken at each degree of latitude, from $10^{\circ} \mathrm{N}$ to $28^{\circ} \mathrm{N}, 6^{\circ} \mathrm{N}$ to $19^{\circ} \mathrm{N}$, and $8^{\circ} \mathrm{N}$ to $14^{\circ} \mathrm{N}$, respectively. In Morocco, the transect was further continued SW/NE up to the Mediterranean coast.

iii) Based on the results of the transect studies, additional surveys were conducted in Senegal, The Gambia, Mauritania, Mali and Niger in order to determine either on a $10 \mathrm{~km}$ square scale (Western Senegal) or on a half or quarter square degree scale the southern and eastern limits of the geographic distribution of Ornithodoros species.

iv) We also undertook additional surveys in selected areas of Morocco, Algeria, Tunisia, Niger, Guinea, Guinea Bissau, Liberia, Ivory Coast, Burkina Faso and Togo. All surveys were conducted in predefined sites based on their geographic position. One site south of Spain, where the first studies on TBRF in Europe were conducted in the 1920s by Sadi de Buen [32], was also sampled for comparison of local tick population with African Ornithodoros species.

For each sampling site, as a general rule 30 to 60 burrows were investigated ( 60 burrows during transect studies when all burrows were negative for the presence of Ornithodoros ticks, 30 burrows when one or more burrows were positive; only 30 burrows even when all were negative during additional surveys), except in sites rapidly positive during additional 
surveys in North Africa where only 5 to 15 burrows were investigated. Ticks were collected by introducing a flexible tube inside burrows and aspirating their contents using a portable petrol-powered aspirator. After collection, they were immediately stored in absolute ethanol (one tube per positive burrow) until morphological determination and DNA extraction. As a general rule, two or three sampling stations were selected in each site, including one village (except in most Saharan and North African sites) where several houses were surveyed for the occurrence of ticks both inside burrows and in cracks in the floor or walls. Outside villages, sampling stations were selected according to local environment either in natural or humanimpacted ecosystems and croplands or both of them.

\section{Small mammals sampling}

To investigate the reservoir of Borrelia, we captured rodents and insectivores in Senegal, Mali, Benin, Niger, Chad, Cameroon, Mauritania and Morocco. These collections were made along $12^{\circ} \mathrm{W}, 2^{\circ} \mathrm{E}$ and $14^{\circ} \mathrm{E}$ meridians and in further sites in Senegal, Mali and Morocco. Animals were trapped alive with lattice-work traps baited with peanut butter or onions. We adopted the method of trap lines for captures, with a 10-meter space between traps. In order to collect both diurnal and nocturnal species traps were placed in the afternoon and withdrawn late in the morning. Approximately 200 traps/days of captures were made in each site. In addition, hand captures of rodents were performed by night in most sites and during travel between sites. We necropsied trapped animals in the field by means of cervical dislocation and drew $1 \mathrm{~mL}$ of blood from each by cardiac puncture. We immediately prepared a thick blood film for detection of Borrelia. Samples of brain were stored in nitrogen then at $-80^{\circ} \mathrm{C}$ for further intraperitoneal inoculation to white mouse as previously described [40] and/or Borrelia molecular studies as described below.

The nomenclature here adopted follows Wilson \& Reeder [41] unless otherwise mentioned [42]. Classical body measurements were taken and some individual rodents were kept alive for further chromosomal analyses, as described in Granjon \& Dobigny [43]. Most of the rodents of the SaheloSudanian region could be diagnosed to the species level based on our morphological, ecological and biogeographical knowledge on rodents from this geographic area [42]. However, molecular or chromosomal data were necessary to confirm unambiguously the specific determination of some specimens of the genera Arvicanthis, Gerbillus, Gerbilliscus, Mastomys, and Taterillus especially. This was done according to methods previously described [43-47]. Shrews were determined on the basis of external and skull criteria [Granjon et al, unpublished]. A selection of voucher specimens was kept in formalin or ethanol and is housed at IRD (UMR 22, Dakar and Montpellier). Organ samples as well as DNA and bone marrow cells extracts that have been used for molecular/ cytogenetic studies are also kept in the IRD tissue collection.

\section{DNA isolation and PCR amplification in ticks}

Ticks were individually washed in three sterile water baths, air dried and collected in sterile microtubes. DNA was individually crushed by shaking with a bead beater (mixer mill
MM301, Qiagen, Hilden, Germany), and then DNA was isolated and purified using the DNeasy Blood and Tissue extraction Kit (Qiagen).

For each tick, 16S rRNA was amplified by PCR with Tm16S +1 (5'-CTGCTCAATGATTTTTTAAATTGC-3') and Tm16S-1 (5'-CCGGTCTGAACTCAGATCATGTA-3') primers designed by Fukunaga et al. [48]. The sequenced product size was around $450 \mathrm{bp}$ long and PCRs were performed with the Multiplex PCR Kit (Qiagen) in a $25 \mu$ l volume containing $12.5 \mu$ l of $2 x$ Multiplex PCR Master Mix (Qiagen), $2 \mu \mathrm{M}$ of each Primer, $2.5 \mu \mathrm{l}$ of $\mathrm{Q}$ solution and $4 \mu \mathrm{l}(40-100 \mathrm{ng} / \mu \mathrm{L})$ of DNA template. The amplification cycle involved a denaturation step at $95^{\circ} \mathrm{C}$ for 15 min followed by 10 cycles of $1 \mathrm{~min}$ at $92^{\circ} \mathrm{C}, 1.5 \mathrm{~min}$ at $48^{\circ} \mathrm{C}$, and $1.5 \mathrm{~min}$ at $72^{\circ} \mathrm{C}$ and 32 cycles of $1 \mathrm{~min}$ at $92^{\circ} \mathrm{C}, 1.5 \mathrm{~min}$ of $54^{\circ} \mathrm{C}$, and $1.5 \mathrm{~min}$ of $72^{\circ} \mathrm{C}$. A final extension step was carried out for $10 \mathrm{~min}$ at $72^{\circ} \mathrm{C}$. The amplified products were detected by electrophoresis on 1.5\% agarose gel in TAE 0.5X buffer and staining with Envision (Amaresco). Remaining reaction mixtures were stored at $-20^{\circ} \mathrm{C}$ for direct sequencing.

\section{Detection of Borrelia infections in ticks and small mammals}

DNA isolation was conducted as above. Borrelia detection was based on nested PCR amplification of a $350 \mathrm{bp}$ fragment of the flagella gene (FLA). This gene encodes the periplasmic protein peculiar to Borrelia. The amplification was performed using primers (Bfpad and Bfpdu for the first PCR, Bfpbu and Bfpcr for the second PCR) designed for B. duttonii [48]. Each PCR was performed in a $25 \mu \mathrm{l}$ volume containing $5 \mu \mathrm{l} 5 \mathrm{X}$ buffer (Promega), $2 \mathrm{mM} \mathrm{MgCl}, 200 \mu \mathrm{M}$ of each dNTP, $0.2 \mu \mathrm{M}$ of each primer and 2.5 unit of GoTaq DNA polymerase (Promega). $3 \mu$ l of DNA template was added in the first reaction and $1 \mu$ of the first amplified product was added in the second reaction. Amplification cycles consisted of an initial DNA denaturation step at $94^{\circ} \mathrm{C}$ for 3 min followed by 30 cycles of 40 sec at $94^{\circ} \mathrm{C}, 40 \mathrm{sec}$ at $55^{\circ} \mathrm{C}$ for the first PCR and $51^{\circ} \mathrm{C}$ for the second $\mathrm{PCR}$, and $40 \mathrm{sec}$ at $72^{\circ} \mathrm{C}$. A final extension step was carried out for $10 \mathrm{~min}$ at $72^{\circ} \mathrm{C}$.

For the 16S-23S ribosomal RNA intergenic spacer (IGS), rrs $r r I A$ intergenic spacer IGS/F and IGS/R for the first PCR and rrs rrIA IGS/Fn and IGS/Rn for the second PCR were amplified as previously described [49]. Each PCR was performed in a $25 \mu \mathrm{l}$ volume containing $5 \mu \mathrm{l} 5 \mathrm{X}$ buffer (Promega), $2 \mathrm{mM} \mathrm{MgCl}_{2}, 200$ $\mu \mathrm{M}$ of each dNTP, 5 picomoles of each primer and 2.5 unit of GoTaq DNA polymerase (Promega). $2 \mu$ l of DNA template was added in the first reaction and $1 \mu \mathrm{l}$ of the first amplified product was added in the second reaction. Amplification cycles consisted of an initial DNA denaturation step at $94^{\circ} \mathrm{C}$ for 3 min followed by 35 cycles of $30 \mathrm{sec}$ at $94^{\circ} \mathrm{C}, 30 \mathrm{sec}$ at $56^{\circ} \mathrm{C}, 30 \mathrm{sec}$ at $72^{\circ} \mathrm{C}$ and a final extension $5 \mathrm{~min}$ at $72^{\circ} \mathrm{C}$ for the first PCR. For the second PCR, amplification cycles consisted of an initial DNA denaturation step at $94^{\circ} \mathrm{C}$ for $3 \mathrm{~min}$ followed by 40 cycles of $30 \mathrm{sec}$ at $94^{\circ} \mathrm{C}, 30 \mathrm{sec}$ at $60^{\circ} \mathrm{C}, 30 \mathrm{sec}$ at $72^{\circ} \mathrm{C}$ and a final extension $5 \mathrm{~min}$ at $72^{\circ} \mathrm{C}$ for the first PCR. A final extension step was carried out for $5 \mathrm{~min}$ at $72^{\circ} \mathrm{C}$. The amplified products were detected by electrophoresis as above. Negative control was included in each nested PCR analysis to monitor contamination and false-positive amplification. To rule out amplicon carry- 
over, nucleotide-free water negative control was used throughout the steps of the protocol. The sequence-derived data reported herein were authentified as negative controls introduced in every PCR experiment remained negative, excluding the possibility of cross-contamination during the experiments. The amplified products for 16S rDNA, IGS and FLA were directly sequenced by Eurofins (Ebersberg, Germany).

\section{Sequence alignment and phylogenetic inferences}

All sequences obtained were aligned using ClustalW (v.1.8.1 in BioEdit v.7.0.5.3.) [50]. Maximum Likelihood (PhyML) tree reconstruction was conducted from the 16S rRNA aligned sequences (457 nucleotides) of ticks. For each Borrelia of soft tick, the FlaB gene (FLA, 269 nucleotides) and Intergenic Spacer (IGS, 510 nucleotides) sequences were concatenated for the phylogenetic analyses (PhyML). For each dataset, we used Modeltest 3.4 [51] to select the appropriate model of molecular evolution. The best-fitting ML model was HKY85 [52] for 16S rRNA sequences and GTR (General Time Reversible + Gamma distribution) for IGS-FLA concatened sequences. The highest-likelihood DNA and corresponding bootstrap support values were obtained by PhyML (freely available at http:// mobyle.pasteur.fr/cgi-bin/portal) using NNI (Nearest Neighbor Interchange) branch swapping and 100 bootstrap replicates [53].

Molecular distances with standard error estimate were conducted using the Kimura 2-parameter model among Ornithodoros $16 \mathrm{~S}$ sequences and among Borrelia concatened IGS-FLA sequences as used in other phylogenetical pathogens/vectors studies [54,55]. In the final dataset, the analysis involved 165 different sequences grouping $82116 \mathrm{~s}$ RNA tick sequences and 105 different sequences grouping 216 IGS-FLA Borrelia sequences. Evolutionary analyses were conducted in MEGA 5 [56] and all positions containing gaps and missing data were eliminated.

Phylogenetic analyses of Ornithodoros moubata 16S rRNA (GenBank accession number AB073679), O. porcinus (GenBank acc. no. AB105451), O. turicata (GenBank acc. no. L34327), and O. parkeri (GenBank acc. no. EU009925) were treated as outgroups. Borrelia crocidurae (GenBank acc. no. GU350723 and NC017808), B. duttonii (GenBank acc. no. DQ000279 and DQ346833), B. hispanica (GenBank acc. no. GU350718 and GU357614), B. merionesi (GenBank acc. no. JX257047 and JX257050) and B. recurrentis (GenBank acc. no. DQ000277 and DQ346814) for the IGS and FLA sequences were concatened for the phylogenetic analyses of spirochetes.

In the goal of molecular diagnostic of Ornithodoros species of North and West African countries, we determined Single Nucleotide Polymorphism (SNP) based on 16S rRNA sequences using parsimony-informative site.

\section{Analysis of environmental factors}

We investigated relationship between environmental factors (latitude, longitude, mean annual temperature, mean annual rainfall [57], elevation and distance to the seashore) and tick species distribution using a linear discriminant analysis. All calculations were performed with $\mathrm{R}$ software [58].

\section{Nomenclatural acts}

The electronic edition of this article conforms to the requirements of the amended International Code of Zoological Nomenclature, and hence the new names contained herein are available under that Code from the electronic edition of this article. The published work and the nomenclatural acts it contains have been registered in ZooBank, the online registration system for the ICZN. The ZooBank LSIDs (Life Science Identifiers) can be resolved and the associated information viewed through any standard web browser by appending the LSID to the prefix http://zoobank.org/. The LSID for this publication is: urn:Isid:zoobank.org:pub:583BB2C2B859-4EB5-85D7-70945C923642. The electronic edition of this work was published in a journal with an ISSN, and has been archived and is available from the following digital repositories: PubMed Central, LOCKSS.

The holotypes and paratypes of the new species are deposited at the Institut Royal des Sciences Naturelles de Belgique, Brussels, Belgium (IRSNB). Sequences obtained from a segment of leg of one or several specimens of the type series are deposited in GenBank.

\section{Ethics Statement}

The study protocol was approved by the Steering Committee of the IRD Special Programme Evolution Climatique et Santé (IRD, Montpellier, France), reference project ATI-ECS-07-H/ 2002. Animals were treated in a humane manner, and in accordance with authorizations and guidelines of the American Society of Mammalogists (Animal Care and Use Committee 1998). Captures of rodents and insectivores (Senegal, Mali, Benin, Niger, Cameroon, Chad, Mauritania, Morocco) and ticks (Senegal, Mali, Burkina Faso, Niger, Cameroon, Chad, Guinea Bissau, Guinea, Gambia, Liberia, Côte d'Ivoire, Togo, Benin, Mauritania, Morocco, Algeria, Tunisia, Spain) excluded national parks and protected areas, did not involve endangered or protected species (CITES, UICN, and national guidelines), and were conducted as part of research agreements between IRD, national institutions, national ministries of health and/or scientific research. All tick, rodent and insectivores captures inside houses and private lands were conducted after the owner of the house and land gave permission to conduct the study on this site.

\section{Results}

\section{Geographic distribution of Ornithodoros ticks}

We investigated the occurrence of Ornithodoros ticks in 9,870 burrows from 484 sampling stations in 282 study sites in 12 West African countries (Mauritania, Senegal, The Gambia, Guinea Bissau, Guinea, Mali, Burkina Faso, Niger, Ivory Coast, Benin, Togo, Liberia), three North African countries (Morocco, Algeria, Tunisia), two Central African countries (Cameroon, Chad), and one European country (Spain) (Table S1). 
Table 1. Number of sites and burrows investigated and number and proportion positive for the presence of Ornithodoros ticks.

\begin{tabular}{|c|c|c|c|c|}
\hline \multirow[t]{2}{*}{ Country } & \multicolumn{2}{|c|}{ No. of burrows } & \multicolumn{2}{|l|}{ No. of sites } \\
\hline & Investigated & Positive (\%) & Investigated & Positive (\%) \\
\hline Algeria & 435 & $74(17.0)$ & 24 & $19(79.2)$ \\
\hline Morocco & 605 & 239 (39.5) & 34 & $33(97.1)$ \\
\hline Tunisia & 82 & $23(28.1)$ & 9 & $9(100)$ \\
\hline Mauritania & 905 & $96(10.6)$ & 30 & $12(40.0)$ \\
\hline Senegal & 2.861 & $474(16.6)$ & 61 & $37(60.7)$ \\
\hline The Gambia & 30 & $15(50.0)$ & 2 & $2(100.0)$ \\
\hline Mali & 2.458 & $273(11.1)$ & 69 & $23(33.3)$ \\
\hline Burkina Faso & 210 & $0(0.0)$ & 4 & $0(0.0)$ \\
\hline Niger & 631 & $0(0.0)$ & 13 & $0(0.0)$ \\
\hline Benin & 300 & $0(0.0)$ & 5 & $0(0.0)$ \\
\hline Togo & 150 & $0(0.0)$ & 5 & $0(0.0)$ \\
\hline Ivory Coast & 90 & $0(0.0)$ & 3 & $0(0.0)$ \\
\hline Guinea & 270 & $0(0.0)$ & 7 & $0(0.0)$ \\
\hline Guinea Bissau & 30 & $0(0.0)$ & 1 & $0(0.0)$ \\
\hline Liberia & 60 & $0(0.0)$ & 2 & $0(0.0)$ \\
\hline Chad & 458 & $0(0.0)$ & 8 & $0(0.0)$ \\
\hline Cameroon & 278 & $0(0.0)$ & 4 & $0(0.0)$ \\
\hline Spain & 17 & $2(11.7)$ & 1 & $1(100.0)$ \\
\hline Total & 9.87 & $1,196(12.1)$ & 282 & $136(48.2)$ \\
\hline
\end{tabular}

Ornithodoros ticks morphologically attributable to O. sonrai, $O$. erraticus or $O$. normandi were collected in 136 sites distributed in Morocco, Algeria, Tunisia, Mauritania, Senegal, The Gambia, Mali and Spain (Table 1). In West and Central Africa, all burrows located east of $01^{\circ} \mathrm{E}$ and south of $13^{\circ} \mathrm{N}$ were negative (Figure 1). The southernmost limits were $13^{\circ} 32^{\prime} \mathrm{N}$, $13^{\circ} 35^{\prime} \mathrm{N}$ and $13^{\circ} 54^{\prime} \mathrm{N}$ in Senegal, The Gambia and Mali, respectively, and the easternmost limit south of Sahara was $00^{\circ} 34^{\prime} \mathrm{E}$ in Mali. In all countries where we found Ornithodoros ticks, their distribution was generally contiguous, with rarely a negative site between two positive sites, and thus it has been possible to establish in the field precise distribution limits (i.e. at a few $\mathrm{km}$ scale in western Senegal and at one quarter degree scale in other areas of Senegal and in western Mali). In central and eastern Mali, we found Ornithodoros ticks only in burrows located close to the flood plain of the Niger River. In other areas, the occurrence of Ornithodoros ticks in burrows was independent of any hydrographic system either active or fossil. Based on classical morphological criteria, all Ornithodoros ticks collected in burrows were attributable either to $O$. sonrai (Senegal, The Gambia, Mali, Mauritania, and the most arid areas of Morocco, Algeria and Tunisia), O. erraticus (northern Morocco, northwestern Algeria and a few ticks from northern Tunisia) or $\mathrm{O}$. normandi (northeastern Algeria and northern Tunisia). We never observed O. moubata.

\section{Borrelia infections in small mammals}

A total of 1,629 small mammals belonging to 8 families (rodents: Ctenodactylidae, Dipodidae, Muridae, Nesomyidae,
Sciuridae; insectivores: Erinaceidae, Soricidae; carnivores: Mustelidae) were collected in Senegal, Mauritania, Mali, Niger, Benin, Chad, Cameroon and Morocco (Table S2). As shown in Table 2, these specimens belonged to 50 identified species and a few additional undetermined species. A thick blood film was prepared in 1,270 specimens (Senegal: 80; Mauritania: 224; Morocco: 134; Mali: 413; Niger: 95; Benin: 101; Chad: 52; Cameroon: 171) and brain samples of 1,089 specimens (Senegal: 92; Mauritania: 176; Mali: 322; Niger: 115; Benin: 152; Chad: 52; Cameroon: 180) were inoculated to white mice. As previously reported, brain samples of the 140 specimens collected in Morocco were also studied by PCR [40]. A Borrelia infection was demonstrated in 57 animals from Senegal, Mali, Mauritania or Morocco ( $4.1 \%$ of the 1,386 specimens tested by at least one method) belonging to 13 rodent species and two insectivore species (Table 2). All infected rodents and insectivores were collected in sites or areas where we documented the presence of Ornithodoros ticks. In these areas, we tested 868 animals and the proportion of those found infected by thick blood film examination, brain inoculation and PCR was $3.3 \%$ (28/850), 4.2\% (21/499), and 8.6\% (12/140), respectively. Except for Senegal, where 22.8\% (21/92) of brain inoculations to white mice were positive (all were performed within a few days after sampling), all other brain inoculations to white mice were negative, including those from specimens from Mali and Mauritania with positive thick blood films, this certainly in relation to badly preserved spirochetes in brain tissue after sampling.

\section{Molecular analysis of Ornithodoros ticks and Borrelia infections}

A total of 1,801 Ornithodoros ticks from 113 study sites distributed in 7 African countries (Mali, Senegal, The Gambia, Mauritania, Morocco, Algeria and Tunisia) and in Spain were tested for molecular species determination and associated Borrelia infection. We observed the presence of Borrelia infections in 295 ticks (16.4\%) distributed in all countries and $37.2 \%$ of sites (42/113). We obtained 820 sequences of $16 \mathrm{~S}$ rRNA of Ornithodoros ticks, 216 concatened partial sequences of FlaB gene, and partial sequences of Intergenic spacer for the Borrelia detected (Table 3).

\section{Phylogenetic analysis of Ornithodoros ticks}

The phylogenetic analysis based on 820 16S rRNA sequences divided on 165 unique sequences which clustered in nine entities of Ornithodoros ticks (Figure 2). The genetic distance estimates (Kimura 2-parameters model) between entities varied from $0.062 \pm 0.013$ (O. costalis - O. marocanus distance) to $0.251 \pm 0.030$ (O. merionesi - O. normandi distance) (Table 4). The nine entities were genetically differentiated and hybrids between populations of these areas were known to be infertile [29], indicating that they should be considered as nine different species, including five previously undescribed species (see below and Appendix for designation of types, description of species and criteria for diagnosis):

- O. occidentalis Trape, Diatta, Durand \& Renaud, sp. nov. 


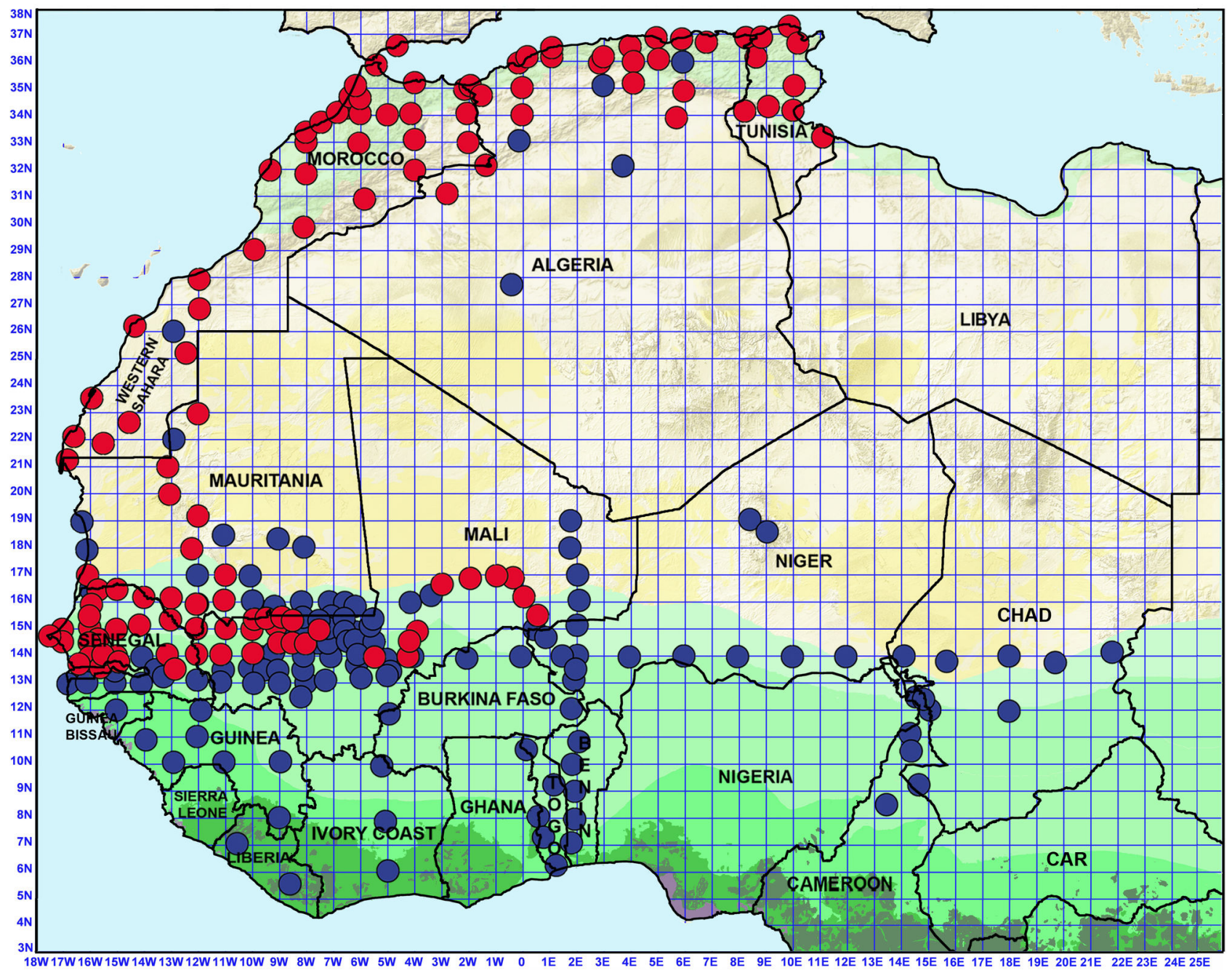

Figure 1. Map of northwestern Africa with the location of study sites positive (red circles) or negative (blue circles) for the occurrence of Ornithodoros ticks in small mammal burrows. At least 30 burrows were investigated in each negative site. doi: 10.1371/journal.pone.0078473.g001

Holotype: IRSNB IG.32.280/004/1; ZooBank: urn:Isid:zoobank.org:act:DC0E7B5B-FBC3-4A7B-

A223-77EOF2CFF2F5; GenBank: KC311536, KC311537.

- O. costalis Diatta, Bouattour, Durand, Renaud \& Trape, sp. nov.

Holotype: IRSNB IG.32.280/005/1; ZooBank: urn:Isid:zoobank.org:act:

43B277DD-7488-4277-8EC6-7AA9653882D0; GenBank: KC311531, KC311532.

- O. rupestris Trape, Bitam, Renaud \& Durand, sp. nov.

Holotype: IRSNB IG.32.280/003/1; ZooBank: urn:Isid:zoobank.org:act:B76003D9-

C807-4194-97C7-1FE7CFA3398D; GenBank: KC311545.
- O. kairouanensis Trape, Diatta, Bouattour, Durand \& Renaud, sp. nov.

Holotype: IRSNB IG.32.280/002/1; ZooBank: urn:Isid:zoobank.org:act:DCC9185B-5FA8-494CBF45-985A60478DC7; GenBank: KC311546.

- O. merionesi Trape, Diatta, Belghyti, Sarih, Durand \& Renaud, sp. nov.

Holotype: IRSNB IG.32.280/001/1; ZooBank: urn:Isid:zoobank.org:act: 8B64EB2B-0288-4488-9E39-94A2E3367FF5; GenBank: KC311538.

The four other species identified were: 0 . erraticus, GenBank: KC311539, KC311540, KC311541, neotype: IRSNB 32.280/006; O. marocanus, GenBank: KC11533, KC311537, KC311535; neotype: IRSNB 32.280/007; O. sonrai, GenBank: KC311525, KC311526, KC311527, KC311528, KC311529, 
Table 2. List of small mammals collected and number of specimens found infected by Borrelia.

\begin{tabular}{|c|c|c|c|c|}
\hline Family & Species & No. collected & No. Tested & No. Infected * \\
\hline \multicolumn{5}{|l|}{ Rodents } \\
\hline Ctenodactylidae & Felovia vae & 1 & 1 & 0 \\
\hline Dipodidae & Jaculus jaculus & 37 & 36 & 0 \\
\hline \multirow[t]{44}{*}{ Muridae } & Acomys airensis & 38 & 28 & 0 \\
\hline & Acomys chudeaui & 17 & 14 & 0 \\
\hline & Arvicanthis ansorgei & 3 & 3 & 0 \\
\hline & Arvicanthis niloticus & 26 & 26 & $1(\mathrm{l}: 1)$ \\
\hline & Arvicanthis rufinus & 5 & 0 & 0 \\
\hline & Arvicanthis spp. & 51 & 38 & 0 \\
\hline & Desmodilliscus braueri & 11 & 8 & 0 \\
\hline & Gerbilliscus gambianus & 5 & 4 & 0 \\
\hline & Gerbilliscus kempi & 4 & 0 & 0 \\
\hline & Gerbilliscus spp. & 54 & 45 & 0 \\
\hline & Gerbillus campestris & 59 & 59 & $4(\mathrm{~B}: 2, \mathrm{P}: 3)$ \\
\hline & Gerbillus gerbillus & 42 & 37 & $1(\mathrm{~B}: 1)$ \\
\hline & Gerbillus henleyi & 1 & 1 & 0 \\
\hline & Gerbillus hoogstraali & 12 & 12 & 1 (B:1, P:1) \\
\hline & Gerbillus pyramidum & 28 & 28 & 0 \\
\hline & Gerbillus nanus & 25 & 21 & 0 \\
\hline & Gerbillus nigeriae & 28 & 26 & 0 \\
\hline & Gerbillus occiduus & 29 & 29 & $1(P: 1)$ \\
\hline & Gerbillus tarabuli & 107 & 90 & $2(\mathrm{~B}: 2)$ \\
\hline & Gerbillus spp. & 41 & 20 & 0 \\
\hline & Lemniscomys barbarus & 1 & 1 & 0 \\
\hline & Lemniscomys bellieri & 2 & 0 & 0 \\
\hline & Lemniscomys zebra & 10 & 8 & 0 \\
\hline & Lemniscomys spp. & 14 & 14 & 0 \\
\hline & Mastomys erythroleucus & 205 & 179 & $9(\mathrm{~B}: 2, \mathrm{l}: 8)$ \\
\hline & Mastomys huberti & 76 & 76 & $1(\mathrm{~B}: 1)$ \\
\hline & Mastomys kollmannspergeri & 38 & 38 & 0 \\
\hline & Mastomys natalensis & 220 & 164 & 7 (B:7) \\
\hline & Mastomys spp. & 26 & 18 & 0 \\
\hline & Meriones libycus & 1 & 1 & 0 \\
\hline & Meriones shawi & 14 & 14 & $6(\mathrm{~B}: 1, \mathrm{P}: 6)$ \\
\hline & Mus musculus & 23 & 15 & $1(\mathrm{I}: 1)$ \\
\hline & Pachyuromys duprasi & 1 & 0 & 0 \\
\hline & Praomys daltoni & 180 & 175 & $11(\mathrm{~B}: 11)$ \\
\hline & Praomys derooi & 15 & 12 & 0 \\
\hline & Rattus norvegicus & 2 & 2 & 0 \\
\hline & Rattus rattus & 18 & 15 & $2(\mathrm{I}: 2)$ \\
\hline & Taterillus arenarius & 7 & 5 & 0 \\
\hline & Taterillus congicus & 2 & 2 & 0 \\
\hline & Taterillus gracilis & 8 & 6 & 0 \\
\hline & Taterillus lacustris & 7 & 5 & 0 \\
\hline & Taterillus petteri & 2 & 2 & 0 \\
\hline & Taterillus spp. & 13 & 10 & 0 \\
\hline & Uranomys ruddi & 15 & 14 & 0 \\
\hline Nesomyidae & Cricetomys gambianus & 7 & 4 & 0 \\
\hline \multirow[t]{3}{*}{ Sciuridae } & Atlantoxerus getulus & 3 & 3 & 0 \\
\hline & Heliosciurus gambianus & 1 & 1 & 0 \\
\hline & Xerus erythropus & 6 & 3 & 0 \\
\hline \multicolumn{5}{|l|}{ Insectivores } \\
\hline \multirow[t]{2}{*}{ Erinaceidae } & Atelerix albiventris & 8 & 2 & 0 \\
\hline & Atelerix algirus & 6 & 6 & $1(P: 1)$ \\
\hline
\end{tabular}


Table 2 (continued).

\begin{tabular}{|c|c|c|c|c|}
\hline Family & Species & No. collected & No. Tested & No. Infected * \\
\hline & Hemiechinus aethiopicus & 3 & 2 & 0 \\
\hline \multirow[t]{3}{*}{ Soricidae } & Crocidura olivieri & 41 & 33 & $9(\mathrm{I}: 9)$ \\
\hline & Crocidura viaria & 9 & 9 & 0 \\
\hline & Crocidura spp. & 20 & 20 & 0 \\
\hline \multicolumn{5}{|l|}{ Carnivores } \\
\hline Mustelidae & Ictonyx striatus & 1 & 1 & 0 \\
\hline
\end{tabular}

KC311530, neotype: IRSNB 32.280/007; and O. normandi, GenBank KC311542, KC311543, KC311544.

Figure 3 shows that high specific diversity was observed in North Africa where the nine species were found and presented either a wide distribution in the most arid areas of Morocco, Algeria and Tunisia (one species: $O$. sonrai), or various restricted distribution patterns in coastal and/or inland areas of North Africa and Spain (eight species).

In West Africa, only O. sonrai was observed, and analysis performed on the $16 \mathrm{~S}$ sequences of $533 \mathrm{O}$. sonrai ticks from 72 study sites in Sudanian, Sahelian and Saharan areas showed a large distribution of $O$. sonrai in West and North Africa (Figure 3). However, over the whole molecular range observed for this species, one group was genetically distinct (bootstrap >90). These ticks were sampled in an area extending from northwestern Senegal (Dagana, Richard-Toll) to northwestern Mauritania (Nouâdhibou) and the most southern part of Morocco (Adrar Souttouf) and we consider that they constitute a distinct sub-species of $O$. sonrai (Figure 3 ).

\section{Phylogenetic analysis of Borrelia}

The phylogenetic analysis of Borrelia was based on 105 different sequences among 216 IGS-FLA sequences obtained. Figure 4 shows that three Borrelia species were present in sampled ticks: $B$. crocidurae, $B$. hispanica, and a third species, $B$. merionesi, a rare spirochaete that was formerly described from Ornithodoros ticks collected in the same area of southern Morocco than our specimens [59,60] (Figure 5). The genetic distance estimates among Borrelia species varied from $0.003 \pm 0.002$ ( $B$. recurrentis - $B$. duttonii distance) to $0.076 \pm 0.010$ (B. hispanica - B. recurrentis distance) (Table 5). Sequences of $B$. crocidurae previously obtained from patients from Dielmo (Senegal) [39] and B. hispanica from patients from Kenitra, Morocco [30] were identical to those collected in Ornothodoros ticks in the same areas.

The IGS-FLA phylogenetic analysis indicated that $B$. crocidurae was only found in O. sonrai (196 out of 533 specimens, $36.7 \%)$, B. hispanica was found in 0 . marocanus $(5 / 43,11.6 \%), \quad O$. occidentalis $(3 / 55,5.5 \%)$ and $O$. kairouanensis $(1 / 5,20.0 \%)$, and $B$. merionesi was found in $O$. costalis $(3 / 65,4.6 \%)$ and $O$. merionesi $(3 / 16,18.8 \%)$. No Borrelia infection was detected in 28 specimens of $O$. rupestris from 2 study sites, nor in 44 specimens of $O$. erraticus from 5
Table 3. Distribution and prevalence of infected Ornithodoros ticks by Borrelia in seven North and West Africa countries and in one locality of Spain.

\begin{tabular}{|c|c|c|c|c|c|c|}
\hline \multirow[b]{2}{*}{ Country } & \multirow{2}{*}{\multicolumn{2}{|c|}{$\begin{array}{l}\text { No. of } \\
\text { ticks } \\
\text { Sites tested }\end{array}$}} & \multirow[b]{2}{*}{$\begin{array}{l}\text { No. of } \\
\text { infected } \\
\text { ticks }\end{array}$} & \multicolumn{3}{|c|}{ No. of IGS-FLA } \\
\hline & & & & \multicolumn{2}{|c|}{$\begin{array}{l}\text { Borrelia } \\
\text { concatened } \\
\text { sequences } \\
\text { Prevalence(786 nu.) }\end{array}$} & $\begin{array}{l}\text { No. of } 16 S \\
\text { rDNA tick } \\
\text { sequences } \\
\text { (457 nu.) }\end{array}$ \\
\hline Algeria & 18 & 199 & 5 & 2.5 & 2 & 183 \\
\hline Gambia & 1 & 8 & 4 & 50.0 & 4 & 1 \\
\hline Mali & 18 & 273 & 34 & 12.5 & 26 & 88 \\
\hline Mauritania & 9 & 72 & 7 & 9.7 & 7 & 21 \\
\hline Morocco & 29 & 415 & 40 & 9.6 & 24 & 188 \\
\hline Senegal & 28 & 768 & 199 & 25.9 & 146 & 281 \\
\hline Spain & 1 & 4 & 2 & 50.0 & 2 & 1 \\
\hline Tunisia & 9 & 62 & 4 & 6.5 & 4 & 57 \\
\hline Total & 113 & 1801 & 295 & 16.4 & 215 & 820 \\
\hline \multicolumn{7}{|c|}{$\begin{array}{l}\text { The number of partial sequences obtained of concatened Intergenic spacer - FlaB } \\
\text { gene (IGS-FLA) for Borrelia and 16S rDNA for ticks are shown. No.: number; Nu } \\
\text { nucleotide. }\end{array}$} \\
\hline
\end{tabular}

study sites, nor in 31 specimens of 0 . normandi from 7 study sites.

\section{Diagnostic SNPs of Ornithodoros ticks}

To allow a rapid molecular identification of Ornithodoros species, we highlighted 25 single nucleotide polymorphisms among the 9 species in 16S rRNA sequence dataset (Table 6). We detected at least one diagnostic SNP for each species, i.e. at a given position of the $16 \mathrm{~S}$ sequence a nucleotide type is present in all sequences of a given species and absent in other species. According to species, the total number of diagnostic SNPs that can be used for taxonomic purpose of soft tick of the genus Ornithodoros varied from 1 to 8 (Table 6).

\section{Environmental factors and tick species distribution}

To investigate the relationship between environmental factors and species distribution, we included in the analysis ticks from 110 study sites. Figure 6 shows the projection of the individual ticks on the first factorial plane. The first two axes 


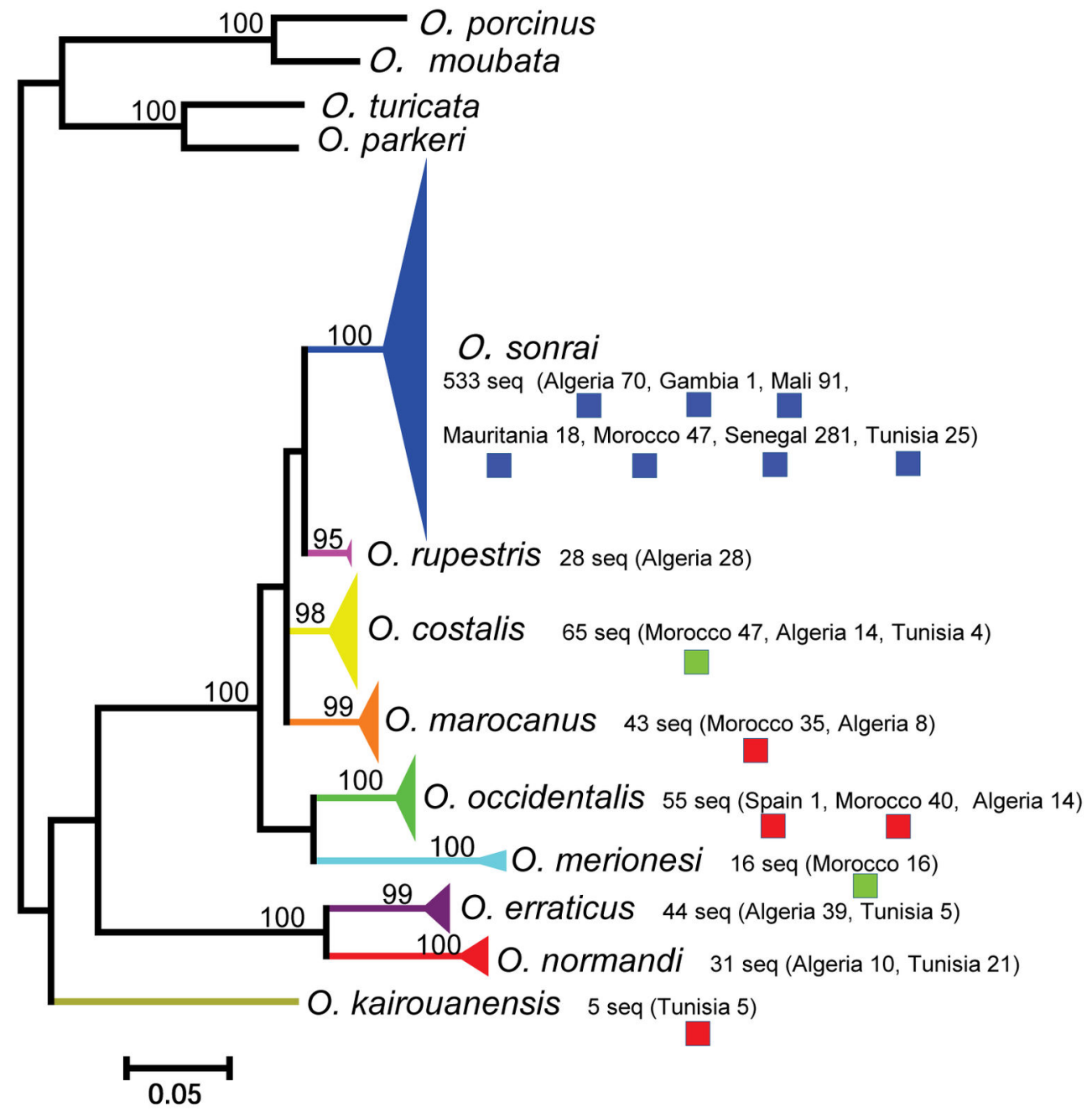

\section{Legend of Borrelia species: $\square$ B. crocidurae $\square$ B. merionesi $\square$ B. hispanica}

Figure 2. Phylogenetic relationships among Ornithodoros species using $16 \mathrm{~S}$ rRNA sequences (820 seq.). The colored triangles indicate the genetic diversity of the sequences detected for each Ornithodoros species. The colored-spots correspond to the Borrelia species detected in each tick species. The phylogram was constructed using a maximum-likelihood method from partial 16S sequence data (457 nucleotides). Bootstrap values $>90$ are shown (Scale bar, 0.05 substitutions per site). Ornithodoros moubata (GenBank accession number AB073679), O. porcinus (GenBank acc. no. AB105451), O. turicata (GenBank acc. no. L34327), and O. parkeri (GenBank acc. no. EU009925) were treated as outgroups. Five of these species are newly described: O. occidentalis, O. costalis, O. rupestris, O. kairouanensis, and O. merionesi.

doi: 10.1371/journal.pone.0078473.g002

explain $92 \%$ of the between-species variance. The predictive power (percentage of well-classified data) is $76 \%$. The variable most positively correlated with axis 1 is the mean annual rainfall (cor $=0.87$ ), the most negatively correlated with axis 1 is mean temperature (cor $=-0.69$ ). The variable most positively correlated with axis 2 is the longitude (cor $=0.81$ ), and the most negatively correlated with axis 2 is elevation (cor = 0.45). O. sonrai lies essentially on the negative part of axis 1 , and thus appears related to drier climates and higher temperature than the other species. O. costalis, O. marocanus, $O$. occidentalis and $O$. merionesi lie generally on the negative part of axis 2 and are not well separated. $O$. normandi and $O$. erraticus lie on the positive part of both axes. Longitude (except for $O$. costalis) and rains (high rains for $O$. erraticus and $O$. normandi, low rains for $O$. merionesi) appear as the most discriminant factors. 
Table 4. Estimates of molecular distance (Kimura 2-parameter model) between the nine Ornithodoros species based on 165 sequences of $16 \mathrm{~S}$ rRNA.

\begin{tabular}{|c|c|c|c|c|c|c|c|c|}
\hline & O. costalis & O. marocanus & O. occidentalis & O. merionesi & O. kairouanensis & O. erraticus & O. normandi & O. rupestris \\
\hline O. sonrai & $0.073(0.013)$ & $0.075(0.013)$ & $0.095(0.017)$ & $0.120(0.019)$ & $0.200(0.025)$ & $0.219(0.025)$ & $0.222(0.026)$ & $0.058(0.012)$ \\
\hline O. costalis & & $0.062(0.013)$ & $0.084(0.015)$ & $0.113(0.020)$ & $0.194(0.022)$ & $0.212(0.023)$ & $0.220(0.026)$ & $0.052(0.011)$ \\
\hline O. marocanus & & & $0.087(0.014)$ & $0.113(0.019)$ & $0.185(0.023)$ & $0.209(0.023)$ & $0.212(0.026)$ & $0.061(0.011)$ \\
\hline O. occidentalis & & & & $0.114(0.019)$ & $0.204(0.026)$ & $0.224(0.025)$ & $0.242(0.028)$ & $0.079(0.015)$ \\
\hline O. merionesi & & & & & $0.203(0.026)$ & $0.230(0.026)$ & $0.251(0.030)$ & $0.114(0.020)$ \\
\hline O. kairouanensis & & & & & & $0.186(0.025)$ & $0.223(0.028)$ & $0.184(0.023)$ \\
\hline O. erraticus & & & & & & & $0.109(0.015)$ & $0.201(0.023)$ \\
\hline O. normandi & & & & & & & & $0.198(0.023)$ \\
\hline
\end{tabular}

Standard error estimates are shown in parenthesis and were obtained by a boostrap procedure (100 replicates).

doi: 10.1371/journal.pone.0078473.t004

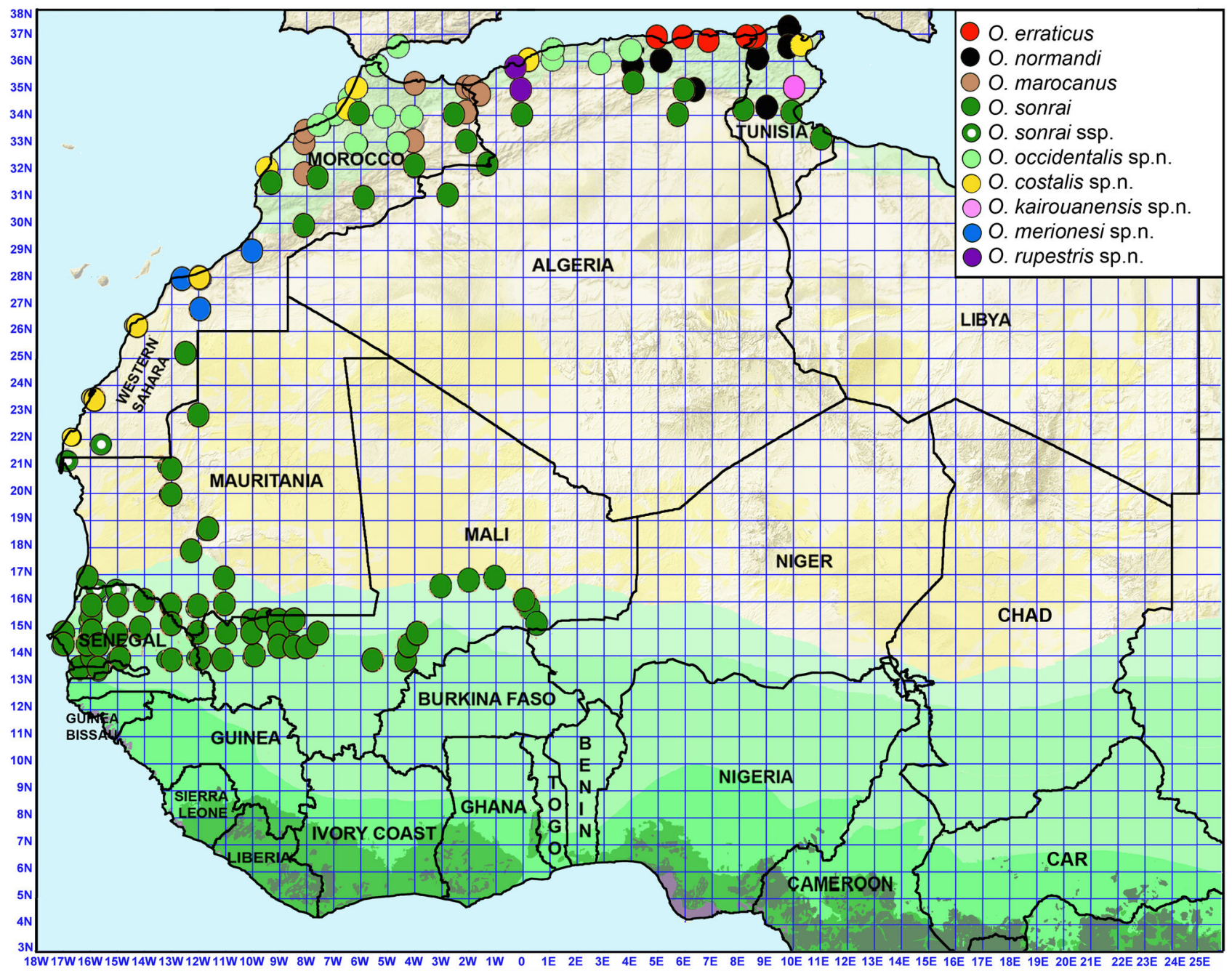

Figure 3. Map of northwestern Africa with the distribution of Ornithodoros species found in small mammal burrows. doi: 10.1371/journal.pone.0078473.g003 


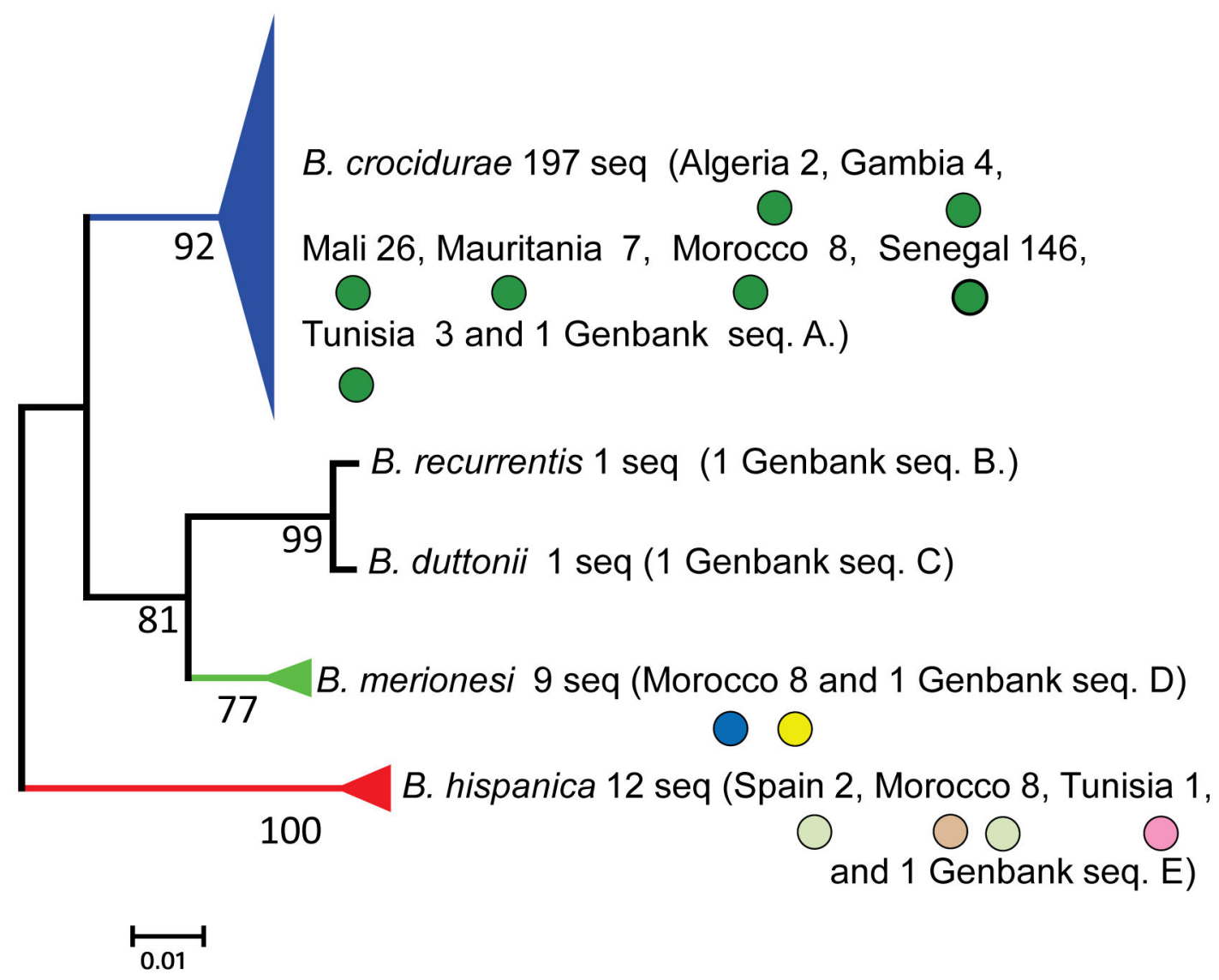

\section{Legend of Ornithodoros species: $\bigcirc$. sonrai $\bigcirc$ O. costalis $\bigcirc$ O. marocanus}

\section{O. occidentalis O. merionesi O.kairouanensis}

Figure 4. Phylogenetic relationships among Borrelia species using partial Intergenic spacer (IGS, 510 nucleotides) and partial FlaB gene (FLA, 269 nucleotides) concatenated sequences. (PhyML 100 bootstraps, available at http:// mobyle.pasteur.fr/cgi-bin/portal.py). The colored triangle estimated the Borrelia species diversity. We included in the $B$. merionesi clade (9 seq.) a Borrelia detected in a rodent captured in El Argoub (Morocco). The colored full circle correspond to the tick species determined by the $16 \mathrm{~S}$ phylogenetic analysis of this study. The phylogram was constructed using a maximum-likelihood method from concatenated sequence data (220 sequences including GenBank reference sequences, 779 nucleotides). Bootstrap values $>70$ are shown (Scale bar, 0.01 substitutions per site). Seq. A.: B. crocidurae (GU350723 and NC017808), seq. B.: B. recurrentis (DQ000277 and DQ346814), seq. C.: B. duttonii (DQ000279 and DQ346833), seq. D.: B. merionesi (JX257047 and JX257050), seq. E.: B. hispanica (GU350718 and GU357614) and concatened sequences were used as references.

doi: 10.1371/journal.pone.0078473.g004

\section{Discussion}

Genetic distances between the nine clades of Onithodoros ticks collected in this study ranged from 5.2 to $25.1 \%$, a distance similar to those found between Ornithodoros species from other parts of the world. For comparison, the genetic distance between $O$. puertoricensis and $O$. rioplatensis, two species from South America, based on 16S rRNA sequencing, is approximately $12.7 \%$ [61]. Morphologically, it was easy to separate these nine species in two groups, the first one comprising two small species distributed in northeastern Algeria and northwestern Tunisia and characterized, among other diagnostic characters, by a transverse groove on coxae I, the second one comprising the seven other species and characterized by an oblique groove on coxae I, as previously illustrated elsewhere [31]. These two groups are confirmed by our molecular study (Figure 2). The two species of the first group includes respectively (a) all specimens from La Calle, 


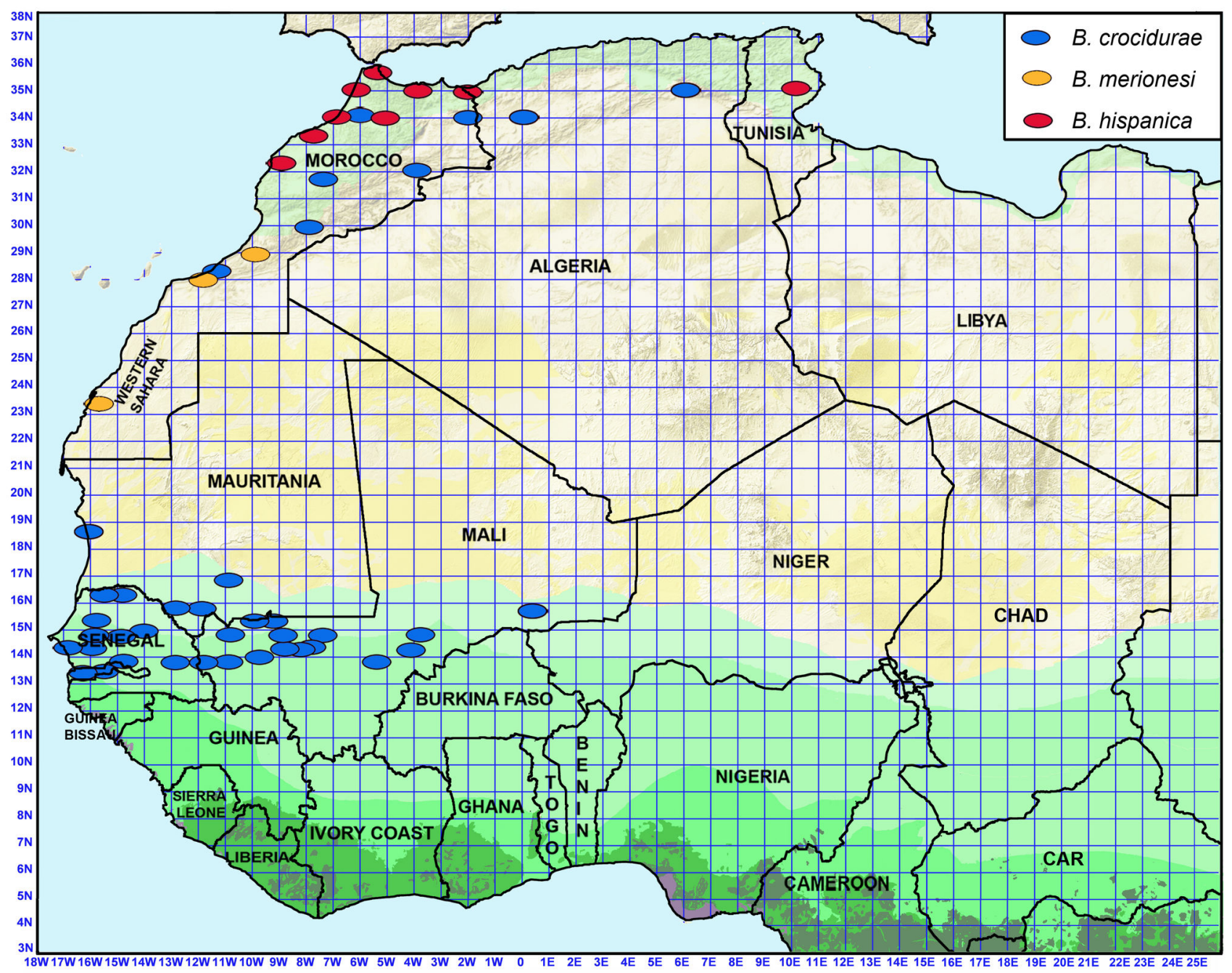

Figure 5. Map of northwestern Africa with the distribution of Borrelia species found in Ornithodoros ticks and/or rodents.

doi: 10.1371/journal.pone.0078473.g005

Algeria - type locality of $O$. erraticus (Lucas, 1849) - and nearby coastal sites of Algeria and Tunisia, and (b) all specimens from Le Kef, Tunisia - type locality of O. normandi Larousse, 1923 and nearby highland sites of Tunisia and Algeria [62,63]. None of 75 specimens of these two species were found infected by $B$. hispanica, B. crocidurae or B. merionesi in this study nor in a previous study in Tunisia [31], suggesting that $O$. erraticus sensu strico and $O$. normandi may be poor vectors or reservoirs of TBRF. By contrast, six of the seven species of the second morphological group of Ornithodoros ticks were found infected by one of these Borrelia species, most often with high prevalence rates (minimum $4.6 \%$ for $O$. costalis, maximum $36.6 \%$ for 0 . sonrai).

Among the seven species of the second group, only two species were previously known: O. marocanus Velu, 1919, type locality "vieille casbah" near Casablanca, Morocco and $O$. sonrai Sautet and Witkovski, 1943, type locality Gao, Mali [64,65]. However, since the work of Colas-Belcour [66], 0.
Table 5. Estimates of molecular distance (Kimura 2parameter model) between the three Borrelia species detected, based on 220 concatened IGS-FLA sequences (779 nucleotides), and comparison with $B$. recurrentis and B. duttonii.

\section{B. crocidurae}

B. hispanica $0.062(0.008) \quad-$

B. merionesi $0.039(0.007) \quad 0.065(0.009)$

$\begin{array}{lllll}\text { B. recurrentis } & 0.043(0.008) & 0.076(0.010) & 0.035(0.006) & \text { - }\end{array}$

$\begin{array}{lllll}\text { B. duttonii } & 0.040(0.007) & 0.073(0.010) & 0.035(0.006) & 0.003(0.002)\end{array}$

Standard error estimates are shown in parenthesis and were obtained by a bootstrap procedure (100 replicates).

doi: 10.1371/journal.pone.0078473.t005 


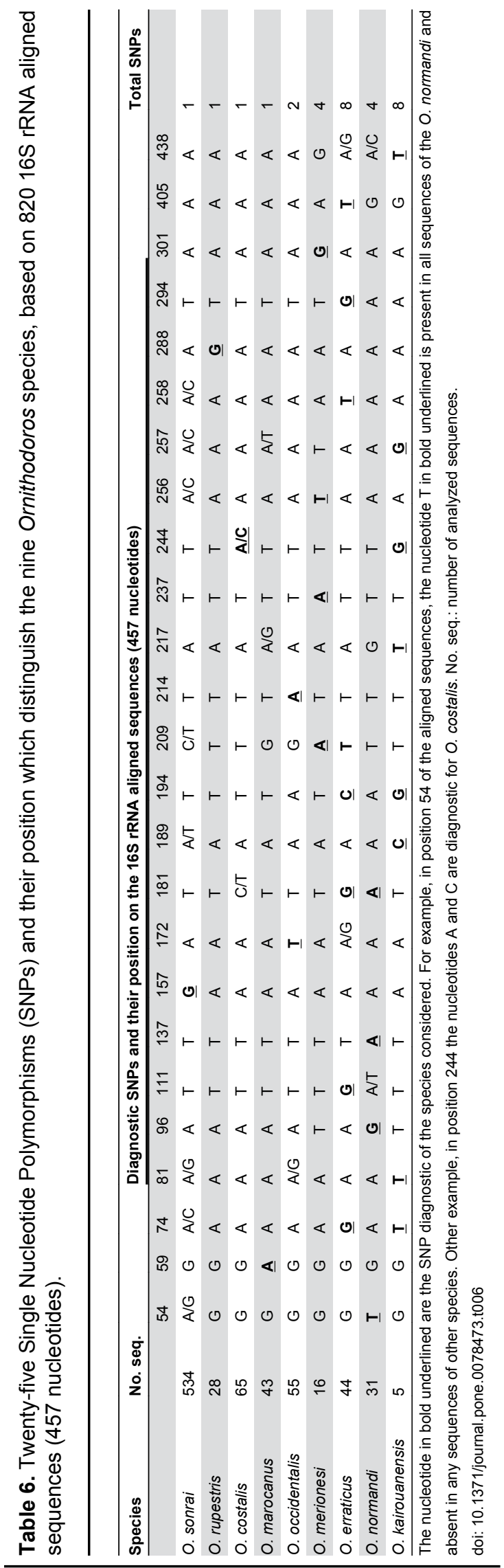




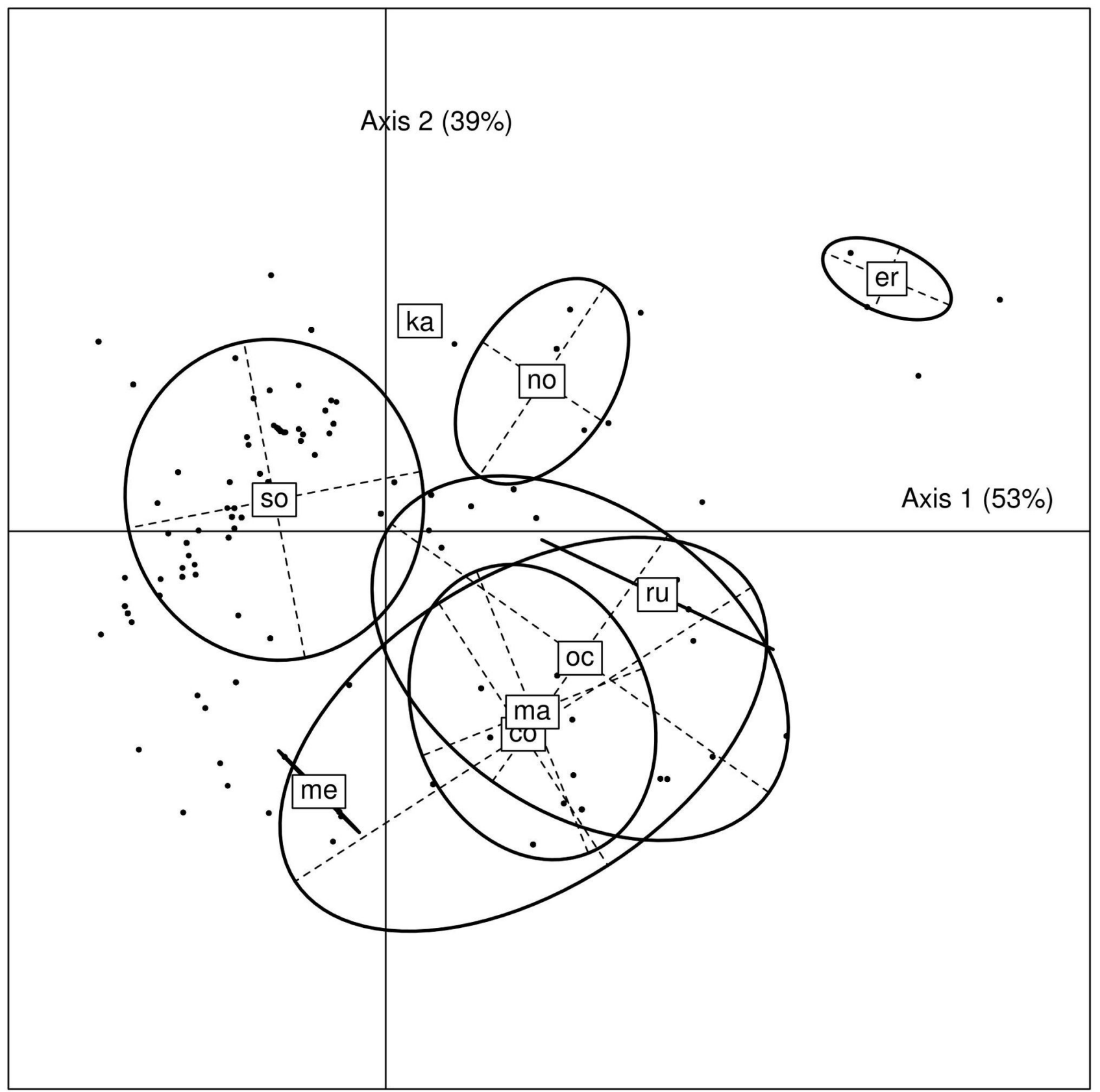

Figure 6. Projection of individual ticks on the first factorial plane of a Linear Discriminant Analysis. All ticks collected in the same location project to the same point. The percentages along the axes labels are the proportions of between-species variance explained by the corresponding linear discriminant. Units have no meaning. The labels indicating each species are located at the center of the individual points belonging to that species. Ellipses encompass around $66 \%$ of the distribution of each species.

Abbreviations: so: O. sonrai, co: O. costalis, ma: O. marocanus, oc: O. occidentalis, me: O. merionesi, ka: O. kairouanensis, er: O. erraticus, no: O. normandi, ru: O. rupestris.

doi: 10.1371/journal.pone.0078473.g006

marocanus was considered as a junior synonym of $O$. erraticus $[67,68]$. Although most Algerian arthropods collected by Lucas [62] were deposited at the Museum National d'Histoire Naturelle in Paris, part of the collection was lost, including the three O. erraticus syntypes. The original description of these specimens was very short and $O$. erraticus was later redescribed by Neumann [69] on the basis of specimens not from La Calle but from Nemours (= Ghazaouet) and Marnia in 
northwestern Algeria near the Moroccan border, an area where our study shows that $O$. erraticus is absent but where $O$. marocanus is widely distributed. Since our study also shows that $O$. erraticus is the only species distributed in coastal areas of northeastern Algeria, from where the three syntypes of Lucas were described [61] and our specimens match their short description, O. marocanus must be resurrected from the synonymy of $O$. erraticus and the distribution of this later species appears much more restricted than previously thought. Morphologically, we failed to find good criteria for distinguishing $O$. erraticus from $O$. normandi, but these two species are clearly distinct genetically and have also distinct ranges and ecological preferences. In addition, comprehensive crossmating experiments between eight populations of $O$. erraticus sensu lato from areas investigated in our study (Casablanca, Oujda, Marrakech, Tunis, Dakar, southern Morocco, southern Spain) and from central and southern Iran performed by Chabaud [29] in the early 1950s indicated that all hybrids of the first or second generation were either sterile or have very low fertility [29]. The results of these experiments combined with our data and the partial sympatry of several of these species clearly support the full specific rank of the seven species of the O. marocanus / O. sonrai group identified in our study (Figure 7).

Interestingly, our data confirm the tick-spirochete species specificity highlighted by previous authors [70]. B. crocidurae was only detected in $O$. sonrai, and both this vector and this spirochete were genetically very close North and South of the Sahara desert, certainly because they present a continuous distribution through Mauritania and Western Sahara (but probably not through central Sahara, a much dryer area [57] where we failed to find $O$. sonrai). The only apparent disjunction in the distribution of this vector was observed in central Mali, where we failed to find a connection between the populations of $O$. sonrai bordering the Niger River and those distributed from western Mali to North Africa. B. hispanica was detected in $O$. marocanus, $O$. occidentalis and $O$. kairouanensis, a complex of three large species (female adult length $5.5-7.5 \mathrm{~mm}$ ) distributed in typically Mediterranean areas of Morocco, Algeria, Tunisia and Spain and previously confused with $O$. erraticus [2,23,28-32,60,66-69]. Finally, the poorly known $B$. merionesi $[59,60]$ appears restricted to Atlantic coastal areas of the Sahara desert where it is transmitted by two Ornithodoros species previously confused with $O$. sonrai: $O$. costalis and $O$. merionesi. Interestingly, no Ornithodoros species was found infected by more than one Borrelia species despite the high prevalence of infected ticks.

The considerable abundance of Ornithodoros TBRF vectors in North and West Africa - from $39.5 \%$ of rodent burrows colonized by vector ticks in Morocco to $13.7 \%$ in West Africa (Senegal, The Gambia, Mali and Mauritania) - coupled with the high infection rate of these vectors by at least two Borrelia species pathogenic for humans suggest that TBRF is a common disease in the whole range of distribution of these vectors. In rural Senegal, we have previously shown that the incidence of $B$. crocidurae TBRF reached 11 per 100 personyears and was the highest described in the world literature for any bacterial disease [39]. In northwestern Morocco, we found
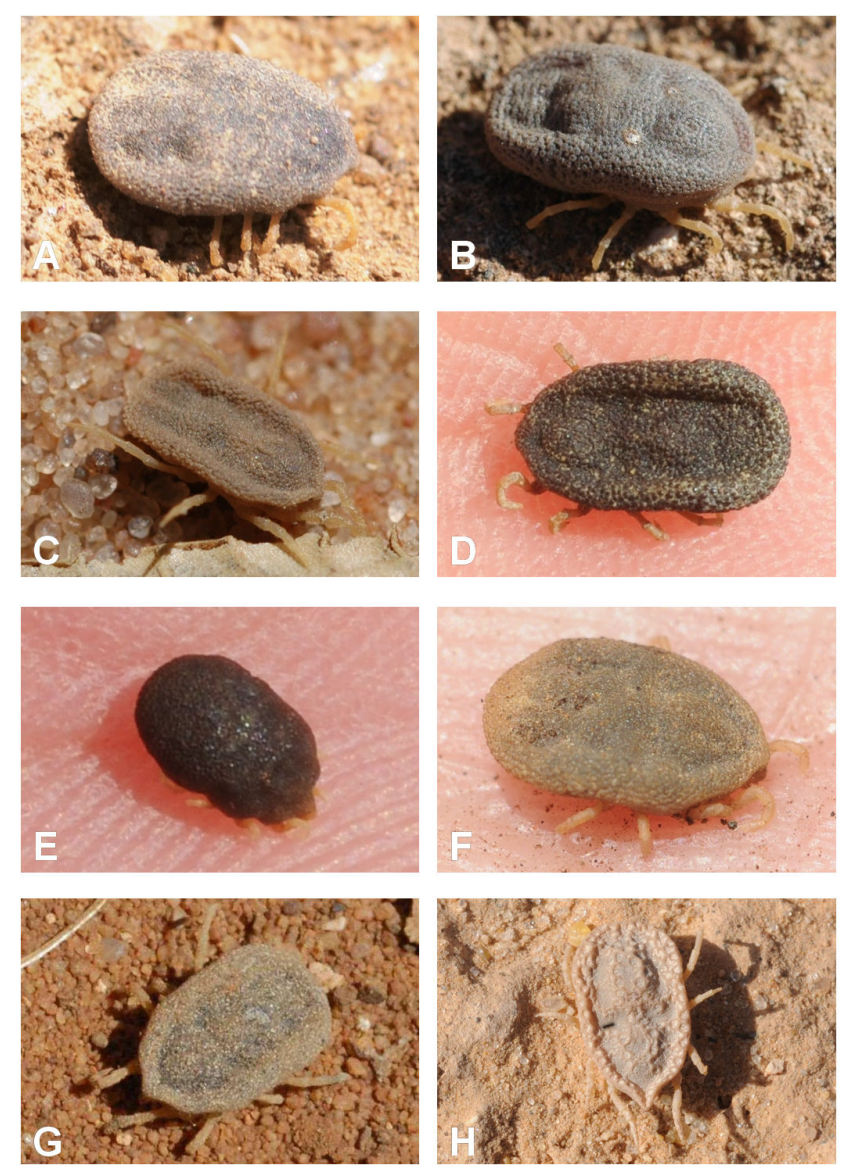

Figure 7. Dorsal view of 0 . erraticus (A), O. marocanus (B), O. sonrai (C), O. costalis (D), O. merionesi (E), 0. occidentalis $(\mathrm{F})$, $O$. rupestris $(\mathrm{G})$, and $O$. kairouanensis (H).

doi: 10.1371/journal.pone.0078473.g007

that $20.5 \%$ of patients with an unexplained fever had $B$. hispanica TBRF [30]. Clearly, similar incidence rates are likely to occur in most areas where we demonstrated the occurrence of one or more of the seven species of the O. marocanus - $O$. sonrai complex. It is not known if $B$. merionesi is also pathogenic for humans. However, a few previous experiments with this spirochete failed to induce TBRF in humans [59].

We consistently failed to find any Ornithodoros tick inside burrows or houses in West Africa south of $13^{\circ} \mathrm{N}$ and east of $01^{\circ} \mathrm{E}$. We also failed to find these ticks in Cameroon and Chad. In the literature, there were in these areas only two mentions of Ornithoros species known as potential vectors of TBRF, one doubtful report of two larvae of $O$. erraticus collected on Arvicanthis niloticus in Ndjamena before 1959 [71] and the mention of one nymph of $O$. sonrai collected in a burrow of Xerus erythropus in Niamey in 1956 [23]. The later report was consistent with the current known distribution of $O$. sonrai along the Niger River in Mali, but our extensive investigations (132 burrows examined) in Niamey and along the Niger River between Niamey and the Malian border were negative. In Mali, a recent comprehensive study of the small mammal reservoir 
of $B$. crocidurae in 20 villages from different areas of the country indicated that $11 \%$ of 663 rodents and $14 \%$ of 63 shrews had antibodies to spirochetes and $2.2 \%$ had confirmed active $B$. crocidurae infections [37]. Interestingly, distribution of seropositive mammals and $O$. sonrai ticks supported our own data, except for some villages of southern Mali where a few rodents were found seropositive although collected south of the known distribution limit of $O$. sonrai. Since low rates of serological cross reactivity and/or dispersal or accidental introduction of rodents south of places where they were infected cannot be excluded, further studies are needed to confirm local transmission of TBRF in these areas. In the Malian study, three rodent species ( $M$. erythroleucus, $M$. natalensis, $P$. daltoni) and two insectivores species (C. olivieri, C. fulvastra) were found infected by thin blood film examination, a method where the amount of blood examined in each microscopic field is approximately 20 -fold less than by thick blood film examination [72]. In Senegal, additional mammal species found infected during previous studies include A. albiventris, $R$. norvegicus, G. gambianus and G. gracilis $[35,36]$. With these species and $C$. fulvastra found infected in Mali [37], the known small mammal reservoir of TBRF in West and North Africa currently comprises 21 species.

A recent study in Togo indicated that $7.9 \%$ and $1.2 \%$ of 239 patients with fever from all regions of the country had $B$. crocidurae and $B$. duttonii infections, respectively, according to PCR blood testing [73]. However, in wet savanna and forest areas of West Africa, Ornithodoros ticks have never been reported $[23,67,74,75]$, and this was confirmed by our surveys in Togo, Benin, Guinea, Guinea Bissau, Ivory Coast and Liberia where a total of 900 burrows and several hundred household examined were negative. If the occurrence of local transmission of $B$. crocidurae and $B$. duttonii in these areas is confirmed (since thick blood films failed to show the presence of spirochetes in PCR positive blood samples in the Togo study), this would suggest the existence of unknown vector / reservoir systems of Borrelia infections in wet savanna areas of West Africa.

Finally, our study as those previously conducted in northern, western, central, eastern and southern Africa [25,39,59,76,77] highlight the need of much more attention from health services, researchers and funding agencies to the continued burden of relapsing fevers due to Borrelia spp. in African populations.

\section{Appendix}

Description of Ornithodoros merionesi, 0 .

kairouanensis, $O$. rupestris, $O$. occidentalis and $O$. costalis, and designation of neotypes for 0 . erraticus,

\section{$O$. marocanus and $O$. sonrai.}

Ornithodoros merionesi. Trape, Diatta, Belghyti, Sarih, Durand \& Renaud, sp. nov.

Holotype: IRSNB/RBINS IG.32.280/001/1, formerly IRD.TRMar7T8M, a nymph of $3.2 \mathrm{~mm}$ long collected on 6 October 2006 inside a rodent burrow in a steppe area located at $29^{\circ} 03^{\prime} 47^{\prime \prime} \mathrm{N} / 09^{\circ} 55^{\prime} 42^{\prime \prime} \mathrm{W}$, approximately $16 \mathrm{~km}$ NE of Guelmin (Morocco), by G. Diatta, Y. Mané and J.F. Trape.
Paratypes: IRSNB/RBINS IG.32.280/001/2-14. Two females, two males and nine nymphs. Same date, location and collectors than the holotype.

Diagnosis: An Argasidae tick of the O. marocanus group of the genus Ornithodoros, characterized by an oblique groove on coxae I., and belonging to the subgroup of small / medium sized species (average female length $<5.2 \mathrm{~mm}$, average male length $<3.0 \mathrm{~mm}$ ) of this complex (subgroup 0 . sonrai complex). Medium sized, morphologically indistinguishable from large specimens of $O$. sonrai and small specimens of $O$. marocanus, but genetically differing from these species and from all other species of the $O$. marocanus group by the unique position of $A$, A, T, and $G$ on 16S rRNA aligned sequences (positions 209, 237, 256 and 301, respectively, see Table 6).

Geographic distribution: Morocco

Ornithodoros kairouanensis. Trape, Diatta, Bouattour, Durand \& Renaud, sp. nov.

Holotype: IRSNB/RBINS IG.32.280/002/1, formerly IRD.TRTun5T3MN, a female of $7.1 \mathrm{~mm}$ long collected on 22 May 2010 inside a rodent burrow in a small cliff bordering a wadi located at $35^{\circ} 03^{\prime} 35^{\prime \prime} \mathrm{N} / 10^{\circ} 02^{\prime} 23^{\prime \prime} \mathrm{E}$, approximately $70 \mathrm{~km} \mathrm{~S}$ of Kairouan (Tunisia), by G. Diatta and J.F. Trape.

Paratypes: IRSNB/RBINS IG.32.280/002/2-3. Two nymphs. Same date, location and collectors than the holotype.

Diagnosis: An Argasidae tick of the $>0$. marocanus group of the genus Ornithodoros, characterized by an oblique groove on coxae I, and belonging to the subgroup of large species (average female length $>5.2 \mathrm{~mm}$, average male length $>3.0$ $\mathrm{mm}$ ) of this complex (subgroup 0 . marocanus complex). This species is characterized by crater-like formations on the soft dorsal cuticle (see Fig. $7 \mathrm{H}$ ). Genetically differing from $O$. marocanus and from all other species of the O. marocanus group by the unique position of T, T, C, G, T, G, G, and T on 16S rRNA aligned sequences (positions 74, 81, 189, 194, 217, 244, 257 and 438, respectively, see Table 6).

Geographic distribution: Tunisia

Ornithodoros rupestris. Trape, Bitam, Renaud \& Durand, sp. nov.

Holotype: IRSNB/RBINS IG.32.280/003/1, formerly IRD.TRAlg12066bMN, a female of $6.1 \mathrm{~mm}$ long collected on 9 June 2012 inside a rodent burrow in a canyon located at $35^{\circ} 56^{\prime} 08^{\prime \prime} \mathrm{N} / 00^{\circ} 05^{\prime} 07^{\prime \prime} \mathrm{E}$ in the town of Mostaganem (Algeria) by J.F. Trape and I. Bitam.

Paratypes: IRSNB/RBINS IG.32.280/003/2-12. Three females, three males and five nymphs. Same date, location and collectors than the holotype.

Diagnosis: An Argasidae tick of the O. marocanus group of the genus Ornithodoros, characterized by an oblique groove on coxae I, and belonging to the subgroup of large species (average female length $>5.2 \mathrm{~mm}$, average male length $>3.0$ $\mathrm{mm}$ ) of this complex (subgroup $O$. marocanus complex). Morphologically indistinguishable from $O$. marocanus, but genetically differing from $O$. marocanus and from all other species of the $O$. marocanus group by the unique position of $G$ on $16 \mathrm{~S}$ rRNA aligned sequences (position 288, see Table 6).

Geographic distribution: Algeria.

Ornithodoros occidentalis. Trape, Diatta, Durand \& Renaud, sp. nov. 
Holotype: IRSNB/RBINS IG.32.280/004/1, a female of 5.3 $\mathrm{mm}$ long collected on 18 July 2010 inside a rodent burrow in a pine woodland located at $36^{\circ} 38^{\prime} 25^{\prime \prime} \mathrm{N} / 04^{\circ} 30^{\prime} 41^{\prime \prime} \mathrm{W}$ near Torremolinos, Spain by G. Diatta and J.F. Trape.

Paratypes: IRSNB/RBINS IG.32.280/004/2-3. Two females. Same date, location and collectors than the holotype.

Diagnosis: An Argasidae tick of the O. marocanus group of the genus Ornithodoros, characterized by an oblique groove on coxae I, and belonging to the subgroup of large species (average female length $>5.2 \mathrm{~mm}$, average male length $>3.0$ $\mathrm{mm}$ ) of this complex (subgroup O. marocanus complex). Morphologically indistinguishable from 0 . marocanus, but genetically differing from $O$. marocanus and from all other species of the $O$. marocanus group by the unique position of $T$ and $A$ on $16 S$ rRNA aligned sequences (positions 172 and 214, respectively, see Table 6 ).

Geographic distribution: Spain, Morocco, Algeria.

Ornithodoros costalis. Diatta, Bouattour, Durand, Renaud \& Trape, sp. nov.

Holotype: IRSNB/RBINS IG.32.280/005/1, formerly IRD.TRTun9T1MN, a female of $6.0 \mathrm{~mm}$ collected on 2 December 2010 inside a rodent burrow located at $36^{\circ} 36^{\prime} 42^{\prime \prime} \mathrm{N}, 10^{\circ} 10^{\prime} 14^{\prime \prime} \mathrm{E}$ near Oudhna (Tunisia) by G. Diatta.

Paratypes: IRSNB/RBINS IG.32.280/005/2-4. Two females and one male. Same date, location and collectors than the holotype.

Diagnosis: An Argasidae tick of the O. marocanus group of the genus Ornithodoros, characterized by an oblique groove on coxae I., and belonging to the subgroup of large sized species (average female length $>5.2 \mathrm{~mm}$, average male length $>3.0$ $\mathrm{mm}$ ) of this complex (subgroup 0 . marocanus complex). Morphologically indistinguishable from $O$. marocanus, but genetically differing from these species and from all other species of the $O$. marocanus group by the unique position $A / C$ on 16S rRNA aligned sequences (position 244, see Table 6).

Geographic distribution: Coastal areas of Morocco, Algeria and Tunisia.

Ornithodoros erraticus. (Lucas, 1849).

The three syntypes of Ornithodoros erraticus are not in Paris MNHN. According to M. Judson (curator for arthropods, personal communication), they were certainly destroyed during transport to Paris as many other specimens of Lucas's collection of Algerian arthropods.

Neotype: IRSNB/RBINS 32.280/006, formerly IRD.TRAlg5T5MN, a female of $3.1 \mathrm{~mm}$ long collected on 8 December 2009 inside a rodent burrow at 36 $53^{\prime} \mathrm{N} / 08^{\circ} 31^{\prime} \mathrm{E}$ near La Calle, Algeria by G. Diatta.

Ornithodoros marocanus. Velu, 1919.

\section{References}

1. Southern PM, Sanford JP (1969) Relapsing fever. A clinical and microbiological review. Medicine 48: 129-149.

2. Rodhain F (1976) Borrelia et fièvres récurrentes: aspects épidémiologiques actuels. Bull Inst Pasteur 74: 173-218.

3. Goubau PF (1984) Relapsing fevers. A review. Ann Soc Belg Med Trop 64: 335-364. PubMed: 6397148.

4. Cadavid D, Barbour AG (1998) Neuroborreliosis during relapsing fever : review of clinical manifestations, pathology, and treatment of infections in humans and experimental animals. Clin Infect Dis 26: 151-164. doi: 10.1086/516276. PubMed: 9455525
The types of 0 . marocanus were sent by Velu [64] to the Pasteur Institute of Paris after he described this species. They could not be traced either in Paris or Casablanca and are now considered as lost (F. Rhodain, personal communication).

Neotype: IRSNB/RBINS 32.280/007, formerly IRD.TRMar16T11ZC, a female of $5.9 \mathrm{~mm}$ long collected on 23 October 2009 inside a rodent burrow at $33^{\circ} 22^{\prime} \mathrm{N} / 08^{\circ} 00^{\prime} \mathrm{W}$ near Casablanca, Morocco by G. Diatta.

Ornithodoros sonrai. Sautet \& Witkowski, 1943.

The types of $O$. sonrai could not be traced either in Paris or Dakar and are now considered as lost (J.-L. Camicas and F. Rodhain, personal communications).

Neotype: IRSNB/RBINS 32.280/008, formerly IRD.TRMalG2T4, a female of $4.0 \mathrm{~mm}$ long collected on 22 January 2005 inside a rodent burrow at $15^{\circ} 59^{\prime} 22$ ' $\mathrm{N} / 00^{\circ} 08^{\prime} 41^{\prime \prime} \mathrm{E}$ in the village of Haousssa Foulane near Gao, Mali by G. Diatta, L. Vial \& J.F. Trape.

\section{Supporting Information}

Table S1. Detailed results of Ornithodoros ticks surveys. (DOCX)

Table S2. Detailed results of small mammals surveys. (DOCX)

\section{Acknowledgments}

We thank Jean-Louis Camicas (IRD, Montpellier) for assistance in tick determination and Stephen C. Barker (University of Queensland, Brisbane) for useful comments on a first draft of the manuscript. We thank all those in Dakar, Bamako, Ouagadougou, Niamey, NDjamena, Yaoundé, Cotonou, Lomé, Lamto, Monrovia, Kindia, Bissau, Nouakchott, Kénitra, Casablanca, Algiers, Annaba, Tunis and Montpellier who provided assistance for field surveys, laboratory work or data analysis.

\section{Author Contributions}

Conceived and designed the experiments: JFT PD FR. Performed the experiments: JFT GD CA IB MS DB AB EE LV YM CB FP GC GM LG JMD PD FR. Analyzed the data: JFT GD EE GM LG JMD PD FR. Contributed reagents/materials/ analysis tools: JFT IB MS DB AB LV YM CB FP GC GM LG JMD PD FR. Wrote the manuscript: JFT GD PR FR.

5. Bryceson ADM, Parry EHO, Perine PL, Warrell DA, Vukotich D et al. (1970) Louse-borne relapsing fever. Q J Med 153: 129-170.

6. Mackie FP (1907) The part played by Pediculus corporis in the transmission of relapsing fever. BMJ 2: 1706-1709. doi:10.1136/bmj. 2.2450.1706. PubMed: 20763589

7. Sergent E, Foley H (1908) Fièvre récurrente du sud-oranais et Pediculus vestimenti. Bull Soc Pathol Exot 1: 174-176.

8. Mathis C (1946) La spirochétose à poux. In : C Mathis. L'œuvre des Pastoriens en Afrique noire (Afrique Occidentale Française). Paris: Presses Universitaires de France. pp. 313-317. 
9. Gaud M, Morgan M (1947) Etude épidémiologique sur la fièvre récurrente en Afrique du Nord (1943-1945). Bull Wrld HIth Org 1: 75-98.

10. Gaud M, Khalil M, Vaucel M (1947) L'évolution de l'épidémie de fièvre récurrente (1942-1946). Bull Wrld Hlth Org 1: 99-107.

11. Garnham PCC, Heisch RB, Timms GL (1947) An epidemic of louseborne relapsing fever in Kenya. Trans $\mathrm{R}$ Soc Trop Med Hyg 41: 140-171. PubMed: 20270461.

12. Weldon ED (1955) World Distribution of Spirochetal Diseases. 2. Relapsing Fevers: Louse-BorneTick-Borne. New York: Map, American Geographical Society.

13. Cutler SJ (2006) Possibilities for Relapsing Fever reemergence. Emerg Infect Dis 12: 369-374. doi:10.3201/eid1203.050899. PubMed: 16704771.

14. Sparrow H (1958) Etude du foyer éthiopien de fièvre récurrente. Bull Wrld HIth Org 19: 673-710.

15. Eguale T, Abate G, Balcha F (2002) Relapsing fever in Hossana, Ethiopia : a clinical and epidemiological study. Ethiop. J Health Sci 12: 103-108.

16. Ramos JM, Malmierca E, Reyes F, Tesfamariam A (2008) Results of a 10-year survey of louse-borne relapsing fever in southern Ethiopia: a decline in endemicity. Ann Trop Med Parasitol 102: 467-469. doi: 10.1179/136485908X300887. PubMed: 18577339

17. Ross PH, Milne AD (1904) Tick Fever. BMJ ii: 1453-1454.

18. Dutton JE, Todd JL (1905) The nature of tick fever in the Eastern part of the Congo Free State, with notes on the distribution and bionomics of the tick. BMJ 2341: 1259-1260.

19. Nicolle C, Anderson $C$ (1928) Présence au Maroc du spirochète de la fièvre récurrente d'Espagne 17. Arch Inst Pasteur Tunis. pp. 83-107.

20. Mathis C, Durieux C (1932) Identité, à Dakar, de Spirochaeta duttoni var. crocidurae et du spirochète infectant dans la nature Ornithodoros erraticus. Bull Soc Pathol Exot $21: 472-485$

21. Leeson HS (1952) The recorded distribution of Ornithodoros moubata (Murray) (Acarina). Bull Entomol Res 43: 407-411. doi:10.1017/ S000748530004058X

22. Walton GA (1962) The Ornithodoros moubata superspecies problem in relation to human relapsing fever epidemiology. In: Aspects of disease transmission by ticks. Symp Zool Soc Lond: 83-153

23. Morel PC (1965) Les tiques d'Afrique et du Bassin Méditerranéen. Maisons-Alfort: IEMVT, 2003

24. Barclay AJG, Coulter JBS (1990) Tick-borne relapsing fever in central Tanzania. Trans R Soc Trop Med Hyg 84: 852-856. doi: 10.1016/0035-9203(90)90106-O. PubMed: 2096523.

25. Goubau PF, Munyangeyo C (1983) Fièvre récurrente à tiques et grossesse. Une étude clinique au Rwanda. Ann Soc Belg Med Trop; 63: 347-355. PubMed: 6667057

26. Hornus $P(1928)$ Note au sujet de la fièvre récurrente marocaine, 17. Tunis: Arch Inst Pasteur. pp. 327-331.

27. Sergent A, Manceaux A, Balliste R (1933) Premier cas de fièvre récurrente hispano-africaine observé en Algérie. Bull Soc Pathol Exot 26: $906-908$

28. Anderson C (1935) Sur la présence d'O. erraticus infecté par Sp. hispanicum dans la banlieue de Tunis. Tunis: Arch Inst Pasteur; 22: 350-363

29. Chabaud AG (1954) L'Ornithodoros erraticus (Lucas 1849) ; multiplicité de ses races. Ann Parasitol Hum Comp 29: 89-130. PubMed: 13181221.

30. Sarih M, Garnier M, Boudebouch N, Bouattour A, Rihani A et al. (2009) Borrelia hispanica relapsing fever, Morocco. Emerg Infect Dis 10: 1626-1629. PubMed: 19861058

31. Bouattour A, Garnier M, M'Ghirbi Y, Sarih M, Gern L et al. (2010) Borrelia crocidurae infection of Ornithodoros erraticus (Lucas, 1849) ticks in Tunisia. Vector Borne Zoonotic Dis 10: 825-830. doi:10.1089/ vbz.2009.0151. PubMed: 20420529

32. De Buen S (1926) Note préliminaire sur l'épidémiologie de la fièvre récurrente espagnole. Ann Parasit 4: 185-192.

33. Mathis C, Durieux C, Advier M (1934) Transmission naturelle et expérimentale à l'homme du spirochète infectant dans la nature, à Dakar, la tique: Ornithodorus erraticus var. marocanus. Ann Inst Pasteur 52: 166-178.

34. Bergeret $C$, Raoult $A(1946)$ La fièvre récurrente à tiques à Dakar. Bull Med AOF 3: 29-56.

35. Boiron H (1949) Considérations sur la fièvre récurrente à tiques au Sénégal. L'importance du rat comme réservoir de virus. Bull Soc Pathol Exot 42: 62-70.

36. Trape JF, Godeluck B, Diatta G, Rogier C, Legros F et al. (1996) The spread of tick-borne borreliosis in West Africa and its relationship to sub-saharan drought. Am J Trop Med Hyg 54: 289-293. PubMed: 8600768.
37. Schwan TG, Anderson JM, Lopez JE, Fischer RJ, Raffel SJ et al. (2012) Endemic foci of the tick-borne relapsing fever spirochete Borrelia crocidurae in Mali. Africa: West, and the potential for human infection. Plos Negl Trop Dis 6, e. p. 1924

38. Trape JF, Duplantier JM, Bouganali H, Rogier C, Legros F et al. (1991) Tick-Borne Borreliosis in West Africa. Lancet 337: 473-475. doi: 10.1016/0140-6736(91)93404-W. PubMed: 1671481.

39. Vial L, Diatta G, Tall A, Ba EH, Bouganali H et al. (2006) Incidence of tick-borne relapsing fever in West Africa: longitudinal study. Lancet 368: 37-43. doi:10.1016/S0140-6736(06)68968-X. PubMed: 16815378.

40. Diatta G, Trape JF, Legros F, Rogier C, Duplantier JM (1994) A comparative study of three methods of detection of Borrelia crocidurae in wild rodents in Senegal. Trans R Soc Trop Med Hyg 88: 423-424. doi:10.1016/0035-9203(94)90412-X. PubMed: 7570827.

41. Wilson DE, Reeder DM (2005) Mammals of the world: a taxonomic and geographic reference, vol $1 \& 2$. Baltimore: John Hopkins University Press. $2142 \mathrm{pp}$.

42. Granjon L, Duplantier JM (2009) Les rongeurs de l'Afrique sahélosoudanienne. Mars IRD: 215.

43. Granjon L, Dobigny G (2003) The importance of chromosomally-based identifications for correct understanding of African rodent zoogeography: Lake Chad murids as an example. Mamm Rev 33: 77-91. doi:10.1046/j.1365-2907.2003.00007.x

44. Lecompte E, Denys C, Granjon L (2005) Confrontation of morphological and molecular data: the Praomys group (Rodentia, Murinae) as a case of adaptative convergences and morphological stasis. Mol Phylogenet Evol 37: 899-919. doi:10.1016/j.ympev. 2005.06.018. PubMed: 16111900

45. Dobigny G, Aniskin V, Granjon L, Cornette R, Volobouev V (2005) Recent radiation in West African Taterillus (Rodentia, Gerbillinae): the concerted role of climatic and chromosome changes. Heredity 95: 358-368. doi:10.1038/sj.hdy.6800730. PubMed: 16106262.

46. Colangelo P, Granjon L, Taylor PJ, Corti M (2007) Evolutionary systematics in African gerbilline rodents of the genus Gerbilliscus: inference from mitochondrial genes. Mol Phylogenet Evol 42: 797-806. doi:10.1016/j.ympev.2006.10.001. PubMed: 17113792.

47. Dobigny G, Tatard C, Kane M, Gauthier P, Brouat C et al. (2011) A cytotaxonomic and DNA-based Survey of rodents from Northern Cameroon and Western Chad. Mamm Biol 76 : 417-427.

48. Fukunaga M, Ushijima Y, Aoki Y, Talbert A (2001) Detection of Borrelia duttoni, a tick-borne relapsing fever agent in Central Tanzania, within ticks by Flagellin gene-based nested polymerase chain reaction. Vector Borne Zoonotic Dis 1: 331-338. doi:10.1089/15303660160025949. PubMed: 12653131.

49. Bunikis J, Tsao J, Berglund J, Fish D, Barbour AG (2004) Sequence typing reveals extensive strain diversity of the Lyme borreliosis agents Borrelia burgdorferi in North America and Borrelia afzelii in Europe. Microbiology 150: 1741-1755. doi:10.1099/mic.0.26944-0. PubMed: 15184561

50. Hall TA (1999) BioEdit: a user-friendly biological sequence alignment editor and analysis program for Windows 95/98/NT. Nucleic Acids Symp S 41: 95-98.

51. Posada D, Crandall KA (1998) MODELTEST: testing the model of DNA substitution. Bioinformatics 14: 817-818. doi:10.1093/bioinformatics/ 14.9.817. PubMed: 9918953.

52. Hasegawa M, Kishino $\mathrm{H}$, Yano $T$ (1985) Dating of the Human-Ape splitting by a molecular clock of mitochondrial-DNA. J Mol Evol 22: 160-174. doi:10.1007/BF02101694. PubMed: 3934395.

53. Guindon S, Gascuel O (2003) A simple, fast, and accurate algorithm to estimate large phylogenies by maximum likelihood. Syst Biol 52: 696-704. doi:10.1080/10635150390235520. PubMed: 14530136.

54. Vitorino L, Chelo IM, Bacellar F, Zé-Zé L (2007) Rickettsiae phylogeny: a multigenic approach. Microbiology 153: 160-168

55. Chausov EV, Ternovoi VA, Protopopova EV, Konovalova SN, Kononova YV et al. (2010) Genetic diversity of tick-borne pathogenes in Tomsk and environs. Entomol Rev 90: 240-250. doi:10.1134/ S0013873810020090.

56. Tamura K, Peterson D, Peterson N, Stecher G, Nei M et al. (2011) MEGA5: Molecular Evolutionary Genetics Analysis using Maximum Likelihood, Evolutionary Distance, and Maximum Parsimony Methods. Mol Biol Evol 28: 2731-2739. doi:10.1093/molbev/msr121. PubMed: 21546353

57. Mahé G, Rouché N, Dieulin C, Boyer JF, Ibrahim B et al. (2012) Carte des pluies annuelles en Afrique / Annual rainfall map of Africa. Bondy: IRD.

58. R-Development Core Team (2006) R: a language and environment for statistical computing. Vienna, Austria: R Foundation for Statistical Computing. 
59. Blanc G, Maurice A (1948) Contribution à l'étude du spirochète de Goulimine. Bull Soc Pathol Exot 41: 139-141.

60. Diatta G, Souidi Y, Granjon L, Arnathau C, Durand P et al. (2012) Epidemiology of tick-borne borreliosis in Morocco. Plos Neg Trop. Drosophila Inf Serv 6: e1810.

61. Venzal JM, Estrada-Peña A, Mangold AJ, González-Acuña D, Guglielmone AA (2008) The Ornithodoros (Alectorobius) talaje species group (Acari: Ixodida: Argasidae): description of Ornithodoros (Alectorobius) rioplatensis $\mathrm{n}$. sp. from southern South America. J Med Entomol 45: 832-840.

doi: 10.1603/0022-2585(2008)45[832:TOATSG]2.0.CO;2.

PubMed: 18826024

62. Lucas H (1849) Exploration scientifique de l'Algérie. Zoologie I. Histoire naturelle des animaux articulés Première partie. Crustacés, arachnides, myriapodes et hexapodes. Paris: Imprimerie Nationale. pp. 316-317. PubMed: 20794664

63. Larrousse $F$ (1923) Présence au Kef (Tunisie) d'une nouvelle espèce du genre Ornithodoros : O. normandi n. sp. Ann Parasit 1: 170-177.

64. Velu H (1919) Existence au Maroc d'une nouvelle espèce d'ornithodore. Bull Soc Pathol Exot 12: 99-104.

65. Sautet J, Witkowski M (1944) A propos d'un ornithodore trouvé à Gao. Bull Soc Pathol Exot; 37: 182-188.

66. Colas Belcour J (1930) Sur l'identité d'Ornithodoros erraticus Lucas et d'O. marocanus Vélu. Arch Inst Pasteur Tunis 19: 1-12

67. Camicas JL, Hervy JP, Adam F, Morel PC (1998) Les Tiques du monde. Nomenclature, stades décrits, hôtes, répartition. / The Ticks of the World Nomenclature, Described stages, Hosts, Distribution (Acarida, Ixodida). Paris ORSTOM: 233.

68. Guglielmone AA, Robbins RG, Apanaskevich DA, Petney TN, EstradaPeña A et al. (2010) The Argasidae, Ixodidae and Nuttalliellidae (Acari: Ixodida) of the world: a list of valid species names. Zootaxa 2528: 1-28.
69. Neumann G (1896) Révision de la famille des Ixodidés. Mem Soc Zool France 9: 25-44.

70. Balthazard M, Bahmanyar M, Modifi C (1950) Ornithodoros erraticus et fièvres récurrentes. Bull Soc Pathol Exot 43: 595-601.

71. Morel PC, Magimel J (1959) Les tiques des animaux domestiques de la région de Fort-Lamy (Tchad) et Fort-Foureau (Cameroun). Ann Parasitol Hum Comp 12: 53-58.

72. Trape JF (1985) Rapid evaluation of malaria parasite density and standardization of thick smear examination for epidemiological investigations. Trans R Soc Trop Med Hyg 79: 181-184. doi: 10.1016/0035-9203(85)90329-3. PubMed: 3890280.

73. Nordstrand A, Bunikis I, Larsson C, Tsogbe K, Schwan TG et al. (2007) Tickborne relapsing fever diagnosis obscured by malaria, Togo. Emerg Infect Dis 13: 117-123. doi:10.3201/eid1301.060670. PubMed: 17370524.

74. Leeson HS (1953) Some notes on the recorded distribution of old world species of Ornithodoros (Acarina). Bull Entomol Res 44: 517-526. doi: 10.1017/S0007485300025591.

75. Hoogstraal H (1956) Ornithodoros. In: Ticks of the Sudan. Cairo, U.S.: Naval Medical Research Unit No. 3, Research Report NM 005 050.29.07, 113-130

76. Cutler SJ, Abdissa A, Trape JF (2009) New concepts for the old challenges of African relapsing fever borreliosis. Clin Microbiol Infect 15: 400-406. doi:10.1111/j.1469-0691.2009.02819.x. PubMed: 19489922.

77. Kisinza WN, McCall PJ, Mitani H, Talbert A, Fukunaga M (2003) A newly identified tick-borne Borrelia species and relapsing fever in Tanzania. Lancet 362: 1283-1284. doi:10.1016/ S0140-6736(03)14609-0. PubMed: 14575974 